\title{
Arketipe peran Ibu dalam cerita rakyat Nusantara dan kontribusinya terhadap terapi lintas budaya
}

\author{
Eggy Fajar Andalas ${ }^{\mathrm{a}, 1^{*}}$, Sugiartib,2 \\ ab Universitas Muhammadiyah Malang, Jalan Raya Tlogomas 246 Malang, 65144, Indonesia \\ 1 eggy@umm.ac.id; ${ }^{2}$ sugiarti@umm.ac.id
}

* Corresponding Author

\begin{tabular}{l}
\hline INFO ARTIKEL \\
Sejarah Artikel: \\
Diterima: 7 September 2021 \\
Direvisi: 14 September 2021 \\
Disetujui: 14 Oktober 2021 \\
Tersedia Daring: 31 Oktober \\
2021 \\
\hline Kata Kunci: \\
Arketipe \\
Cerita Rakyat Nusantara \\
Terapi Lintas Budaya
\end{tabular}
\begin{abstract}
ABSTRAK
Saat ini, sensivitas budaya di bidang psikoterapi menjadi isu yang penting karena tumbuhnya kesadaran bahwa berbagai praktik yang dilakukan selama ini bersifat Eurosentris. Para ahli mengabaikan fakta keberagaman latar belakang budaya pasien. Padahal, banyak terapis yang menangani pasien dari berbagai latar belakang budaya menyadari adanya keunikan budaya pada setiap pasiennya. Sayangnya, belum banyak riset yang berusaha memahami dan menggali kekayaan budaya yang ada dalam cerita rakyat dan dimanfaatkan dalam bidang terapi. Penelitian ini bertujuan mendeksripsikan arketipe peran Ibu dalam cerita rakyat nusantara dan signifikansinya sebagai mental budaya masyarakat dapat berkontribusi terhadap terapi lintas budaya. Penelitian menggunakan 288 cerita rakyat Nusantara. Metode analisis yang digunakan adalah analisis isi dan studi dokumen. Hasil Penelitian menunjukkan dalam imajinasi kolektif masyarakat Nusantara, Ibu arketipe peran Ibu termanifestasi dalam bentuk peran Ibu yang baik, Ibu yang buruk, dan peran Ibu yang bertransformasi. Ibu tidak hanya menjadi sosok protagonis yang memberikan perlindungan, kehidupan, dan kesejahteraan, tetapi juga menjadi antagonis yang mampu menjadi sosok menakutkan bagi anaknya. Dalam oposisi biner ini, sosok Ibu juga mampu bertranformasi dengan mengubah peranannya sesuai dengan konteks situasi yang menyertainya, yaitu Ibu protagonis menjadi sosok antagonis yang diakibatkan oleh ketidakpatuhan anaknya atau hadirnya pihak ketiga. Ketiga arketipe peran Ibu tersebut merupakan gambaran dari imajinasi kolektif masyarakat Nusantara dalam menggambarkan peran Ibu dalam kehidupan sehari-hari. Gambaran ini dapat dimanfaatkan dalam bidang terapi, khususnya dalam proses terapi yang melibatkan pasien anak-anak atau Ibu. Arketipe peran Ibu dapat menjadi gambaran mengenai nilai-nilai yang melekat pada sosok Ibu dan menjadi mental budaya masyarakat Nusantara.
\end{abstract}

\begin{tabular}{ll}
\hline ABSTRACT \\
\hline Keywords: & Currently, cultural sensitivity in the field of psychotherapy has become an \\
Nusantara Folktales & carried out so far are Eurocentric. Experts ignore the fact that the patient's \\
Cross Cultural Therapy & cultural background is diverse. In fact, many therapists who treat patients \\
from various cultural backgrounds are aware of the cultural uniqueness of & each patient. Unfortunately, not much research has tried to understand \\
and explore the cultural richness that exists in folklore and is used in the \\
field of therapy. This study aims to describe the archetype of the mother in \\
the folklore of the archipelago and its significance as a community mental \\
culture that can contrIbute to cross-cultural therapy. The study used 240 \\
Indonesian folk tales. The analytical method used is content analysis and \\
document study. The results of the study show that in the collective \\
imagination of the people of the archipelago, the archetypal mother role \\
is manifested in the form of a good mother role, a bad mother, and a \\
transformed mother role. Mother is not only a protagonist who provides
\end{tabular}




\begin{abstract}
protection, life, and welfare, but also becomes an antagonist who can become a frightening figure for her child. In this binary opposition, the mother figure is also able to transform by changing her role according to the context of the accompanying situation, namely the protagonist's mother becomes an antagonist figure caused by the disobedience of her child or the presence of a third party. The three archetypes of the mother's role are an illustration of the collective imagination of the Indonesian people in describing the role of mothers in everyday life. This picture can be used in the field of therapy, especially in the therapeutic process involving children or mothers. The archetype of the mother's role can be an illustration of the values attached to the mother figure and become the cultural mentality of the Indonesian people
\end{abstract}

(C) 2021, Andalas \& Sugiarti

This is an open access article under CC-BY-SA license

(c) (1) (2)

How to Cite: Andalas, E. F., \& Sugiarti, S. (2021). Arketipe peran Ibu dalam cerita rakyat nusantara dan kontrIbusinya terhadap terapi lintas budaya. Satwika : Kajian Ilmu Budaya dan Perubahan Sosial, 5(2), 152-172, https://doi.org/10.22219/satwika.v5i2.18019

\section{Pendahuluan}

Saat ini, sensivitas budaya di bidang psikoterapi menjadi isu yang penting (Sue \&

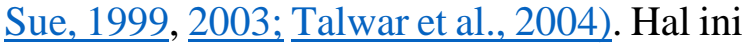
muncul seiring dengan tumbuhnya kesadaran bahwa berbagai praktik yang dilakukan selama ini bersifat Eurosentris (Hocoy, 2002). Para ahli mengabaikan fakta keberagaman latar belakang budaya pasien. Padahal, banyak terapis yang menangani pasien dari berbagai latar belakang budaya menyadari adanya keunikan budaya pada setiap pasiennya (Hocoy, 2002; Talwar et al., 2004). Pemahaman terhadap latar belakang budaya pasien dapat mempengaruhi cara penanganan dan tingkat keberhasilan terapi (Tsang et al., 2011). Saat ini, para terapis diharapkan mampu meningkatkan sensivitas profesionalitas kerjanya dengan meningkatkan pemahaman terhadap latar belakang budaya pasien untuk dapat melakukan terapi yang tepat.

Untuk memahami latar belakang budaya pasien dapat dilakukan dengan berbagai cara, salah satunya melalui interpretasi cerita rakyat yang hidup di masyarakat (Congxin \& Yongxia, 2019; Greene, 2011; Tsang et al., 2011; Walker, 2010). Sejak awal abad ke-20, cerita rakyat telah digunakan oleh psikiater untuk membantu praktik terapi trauma. Karakteristik unik dari cerita rakyat sebagai "hasil budaya kolektif" mencerminkan "identitas" etnis-budaya pemilik cerita (Andalas, 2018; Aristama et al., 2020; Sulistyorini \& Andalas, 2017). Selama bergenerasi cerita diwariskan sebagai "kekayaan budaya" yang mengandung esensi budaya atau DNA budaya (Bar Zaken, 2020). Dengan kata lain, memahami cerita rakyat suatu masyarakat akan diperoleh pengetahuan dan pandangan hidup masyarakat tersebut (Andalas, 2015; Dundes, 1969). Berbagai informasi ini dapat menjadi pedoman bagi terapis dalam memahami pasiennya.

Dalam kurun waktu 10 tahun terakhir, terdapat beberapa riset yang berusaha memahami dan menggali kekayaan budaya yang ada dalam cerita rakyat dan dimanfaatkan dalam bidang terapi. Pertama, dalam bidang ilmu psikoterapi, terdapat beberapa penelitian yang melihat efektivitas penggunaan cerita rakyat dalam terapi mental (Avrahami, 2005; Huet, 2015; Regev \& Cohen-Yatziv, 2018; Ruini et al., 2014; Smith, 2016; Van Lith, 2016). Studi-studi tersebut menujukkan efektivitas penggunaan cerita rakyat dalam mengobati trauma perang, penyakit mental, menurunkan stres, hingga peningkatan kondisi psikologis. Kedua, dalam bidang sastra dan budaya, penelitian dilakukan terhadap dimensi arketipe cerita untuk memahami perilaku 
dan cara berpikir suatu masyarakat (Congxin \& Yongxia, 2019; Greene, 2011; Kaniel, 2015; Kheong et al., 2019; Masuku, 2020; Walker, 2010). Studi-studi tersebut menunjukkan arketipe, sebagai pola ketaksadaran manusia, menjadi dasar bagi suatu kelompok budaya dalam merespon berbagai hal yang ada di sekitarnya. Cara berpikir inilah yang kemudian mengendap dalam berbagai produk budaya masyarakat, termasuk karya sastra, dan menjadi gambaran dari "DNA budaya" masyarakat tersebut. Struktur kebudayaan ini dapat menjadi alat bantu terapis dalam mengenal pasien dan menentukan tindakan yang tepat dalam terapi.

Meskipun telah mendapat perhatian, tetapi penelitian terhadap arketipe "Ibu" dalam cerita rakyat nusantara belum banyak dilakukan, utamanya kontribusinya terhadap bidang terapi seni lintas budaya. Pemahaman terhadap arketipe "Ibu" sebagai bagian dari upaya kontribusi terhadap terapi seni sangat penting karena dalam kultur masyarakat Indonesia, Ibu menempati posisi yang sangat penting (Andalas, 2018). Ibu menjadi menjadi pusat dari berbagai simbolisasi dalam kehidupan masyarakat Nusantara. Karenanya, untuk dapat memahami dengan baik karakteristik budaya masyarakat Indonesia, diperlukan pemahaman terhadap arketipe peran Ibu.

Penelitian ini bertujuan mendeksripsikan arketipe peran Ibu dalam cerita rakyat nusantara sebagai gambaran mental budaya masyarakat dan signifikansi arketipe peran Ibu sebagai mental budaya masyarakat Indonesia dapat berkontribusi terhadap terapi lintas budaya. Penelitian ini berkontribusi dengan diperolehnya konsep mengenai arketipe "peran Ibu" dalam cerita rakyat Nusantara. Hal ini utamanya berkaitan dengan fungsi sastra sebagai media terapi. Pemahaman terhadap kedua hal tersebut penting karena 1) interpretasi arketipe "Ibu" dalam cerita rakyat nusantara merupakan gambaran pandangan dunia kolektif masyarakat Indonesia dalam memandang dan memosisikan peran "Ibu" dalam kehidupan sehari-hari. Gambaran ini dapat membantu terapis yang menangani pasien dari latar belakang Indonesia sekaligus dokumen gambaran keragaman kekayaan budaya Indonesia mengingat Indonesia terdiri dari berbagai latar belakang etnis dan budaya. 2) dalam bidang terapi seni (art therapy), kompetensi lintas budaya merupakan kompetensi penting dalam pendidikan terapi dan riset prioritas utamanya untuk meningkatkan pengetahuan dan sumber rujukan bagi kelompok minoritas (non Eropa-Amerika). 3) arketipe mempengaruhi hal yang kita lakukan, pikirkan, dan rasakan. Bahkan, orang-orang yang ada di sekitar kita. Dengan mengetahui hal tersebut, kita dapat belajar mengenai pola yang mempengaruhi perilaku manusia (human behavior).

Dalam penelitian ini, sosok Ibu dan simbolisasinya, merupakan pusat interpretasi. Dengan melihat sosok Ibu dalam cerita rakyat nusantara dimungkinkan untuk melihat pola psikologis keIbuan sebagai struktur budaya masyarakat Indonesia. Teori arketipe Carl Jung berfungsi sebagai teori utama dalam interpretasi cerita. Hal ini didasarkan asumsi bahwa cerita rakyat memperlihatkan ketaksadaran kolektif sebagai "mimpi kolektif (Jung, 2014; Neumann, 2015). Mimpi kolektif ini merupakan gambaran cita-cita dan harapan suatu masyarakat dalam melihat dan merespon berbagai hal yang ada di sekitarnya. Melalui asumsi dasar inilah, penelitian ini, melihat bahwa realitas sosial, budaya, dan individu saat ini memiliki hubungan sentral kepada sosok Ibu sebagai yang hidup dalam kultur masyarakat (Bar Zaken, 2020).

Teori psikoanalisis menyatakan bahwa Ibu memiliki peranan penting, mendasar, dan substansial dalam perkembangan mental manusia (Sayers, 2014). Hal ini mengingat peran penting Ibu dalam kehidupan seseorang. Karenanya untuk dapat memahami bagaimana perkembangan pola pikir dan perilaku diperlukan pemahaman terhadap aketipe Ibu sebagai sosok sentral dalam perkembangan suatu masyarakat. 
Dalam penelitian psikologi-sastra, teori Jung mengasumsikan bahwa cerita rakyat sebagai "mimpi kolektif" yang berasal dari lapisan terdalam jiwa kolektif umat manusia, bersifat primitif dan kuno, tetapi selalu muncul dalam kesulitan dan harapan nirsadar manusia (Von Franz, 2017). Asumsi utama teori ini adalah sosok Ibu yang hebat dan penggambaran keIbuan berfungsi sebagai dasar fundamental dalam interpretasi cerita rakyat.

Pemahaman terhadap arketipe cerita tidak hanya berfungsi untuk menemukan bentuk arketipe semata. Arketipe bersifat universal. Pada masa lalu, arketipe bermigrasi melalu medium lisan, tetapi saat ini budaya cetak turut membantu distrIbusinya secara luas antargenerasi, lintas budaya, dan lintas peradaban. Arketipe senantiasa ada dan tumbuh dalam masyarakat antargenerasi. Misalnya Kaniel $\underline{(2015)}$, menunjukkan bagaimana sosok Ibu dalam "Bunda Maria" yang hidup dalam mitologi Yahudi menjadi wujud pola dasar wanita yang kualitasnya berakar pada narasi alkitab tentang dinasti Daud. Selain itu, penelitian Masuku (2020) memperlihatkan Ibu merupakan polar masyarakat dan pelindung anak-anak di Afrika. Hal ini tercermin melalui peribahasa dan cerita rakyat yang tumbuh di masyarakat dan menjadi katalisator dalam mengangkat status wanita di masyarakat. Bahkan arketipe dapat digunakan dalam membantu terapi pasien dalam mengatasi permasalahan psikologis. Congxin \& Yongxia (2019), memperlihatkan dengan melakukan interpretasi terhadap simbolisasi ikan, sebagai sosok mitologis yang mengakar dan tumbuh kuat dalam budaya China, dapat membantu terapis dalam mengobati pasiennya. Gambaran-gambaran tersebut memperlihatkan bahwa arketipe menjadi bagian dari kesadaran nasional yang senantiasa diadaptasi seiring kemajuan bangsa (Kheong et al., 2019).

Dalam kerangka studi inilah penelitian ini dilakukan. Melalui telaah terhadap dimensi arketipe, sebagai sumber imajinasi kolektif masyarakat Indonesia dalam memandang berbagai realitas di sekitarnya, akan diperoleh karakteristik dan struktur mental masyarakat Indonesia. Penelitian ini melakukan interpretasi terhadap arketipe "peran Ibu" dalam cerita rakyat nusantara. Penelitian ini didasarkan asumsi bahwa gambaran Ibu dalam cerita rakyat merupakan ekspresi sentral sekaligus vital dari suatu budaya atau individu. Ibu menjadi menjadi pusat dari berbagai simbolisasi dalam kehidupan masyarakat Nusantara.

\section{Metode}

Jenis penelitian yang dilakukan adalah penelitian kualitatif. Penelitian dilakukan dengan metode deskriptif-analitik. Pembacaan cerita pendek dilakukan dengan metode content analysis (analisis isi). Penetuan sumber data dilakukan dengan memperhatikan 1) kehadiran tokoh Ibu, 2) adanya interaksi tokoh Ibu dan anak, 3) asal cerita (mencakup wilayah Indonesia Barat, Tengah, dan Timur). Dalam penelitian ini digunakan 288 cerita rakyat yang diperoleh dari www.ceritarakyatnusantara.com. Laman ini berisikan cerita rakyat yang dihimpun dan dikelola oleh Balai Kajian dan Pengembangan Budaya Melayu Yogyakarta. Dari 288 cerita rakyat kemudian dilakukan penentuan purposive sampling sesuai dengan kriteria yang telah disebutkan.

Data penelitian dihimpun dengan teknik close reading. Secara konkrit kegiatan dilakukan dengan 1) Membaca dengan memperhatikan tema/pola tertentu dalam teks, 2) menganalisa teks yang memperlihatkan tema/pola tertentu (tone, narator, piranti sastra), 3) mengembangkan tesis awal, dan 4) mengonstruksi argumen atas teks. Data yang telah terkumpul kemudian dianalisis menggunakan teknik analisis interaktif model Miles \& Huberman (1992), yaitu reduksi data, penyajian data, interpretasi, dan penarikan kesimpulan.

Melalui temuan pada data ini kemudian dilakukan studi dokumen terhadap berbagai literatur mengenai terapi sastra. Melalui telaah dokumen dilakukan interpertasi korelasi antara temuan arketipe cerita rakyat nusantara dan temuan praktis terhadap 
fungsi sastra dalam terapi untuk menemukan signifikansi penggunaan cerita rakyat dalam terapi, khususnya pasien berlatar belakang budaya Indonesia.

\section{Hasil dan Pembahasan}

Berdasarkan analisis terhadap 288 cerita rakyat Nusantara ditemukan 62 cerita yang sesuai dengan kriteria, yaitu menggambarkan hubungan antara Ibu dan anak. Cerita-cerita tersebut, yaitu 1) Aceh: Banta Seudang, Banta Berensyah, Mentiko Betuah, Si Kepar, Tujuh Anak Laki-Laki, 2) Sumatera Utara: Si Baroar, Si Beru Dayang, Kisah Pohon Enau, Batu Gantung, Kisah Putri Ular, Asal Mula Kolam Sampuraga, Asal Mula Pulau Si Kantan, 3) Sumatera Barat: Asal Mula Nagari Koto Nan Ampek dan Koto nan Gadang, Bujang Kirai yang Pemberani, Asal Mula Sungai Ombilin dan Danau Si, 4) Riau: Hang Tuah Kesatria Melayu, Dang Gedunai, Si Bujang, Legenda Batang Tuaka, Putri Tujuh, Si Lancang, Batu Batungkup, 5) Sumatera Selatan: Baginde Lubuk Gong, Semesat dan Semesit, 6) Bengkulu: Si Gulap yang Sabar, 7) Jambi: Si Kelingking, Tan Talanai, Putri Rainun dan Rajo Mudo, Asal Mula Nama Lempur, Tebat Gelang, dan Tebat Jambi, 8) Lampung: Sang Kabelah, Si Bugu yang Pandir, Si Bungsu, Unang Batin, 9) Bangka Belitung: Bujang Katak, Si Kelingking, Legenda Batu Balai, 10) DKI Jakarta: Si Pitung, 11) Jawa Barat: Putri Kandita, Dayang Sumbi, 12) Yogyakarta: Bawang Merah dan Bawang Putih, 13) Jawa Tengah: Jaka Tarub, Timun Mas, Legenda Rawa Pening, 14) Banten: Legenda Tanjung Lesung, Legenda Gunung Pinang, 15) Jawa Timur: Ande-Ande Lumut, Jaka Sger dan Rara Anteng, 16) Kalimantan Tengah: Palui, 17) Kalimantan Timur: Legenda Pesut Mahakam, 18) kalimantan Barat: Batu Menangis, 19) Kalimantan Selatan: Legenda Gunung Batu Bangkai, Batu Bini dan Batu Laki, 20) Sulawesi Utara: Ratu Adioa, 21) Sulawesi Tengah: Asal Mula Ikan Duyung, Sesentola dan Burung Garuda, 22) Sulawesi Selatan: La Upe, 23) Sulawesi Barat: Cengnge', 24) Sulawesi Tenggara: Asal Mula Burung
Ntaapo-Apo, La Sirimbone, 25) Gorontalo: Limonu yang Perkasa, 26) Nusa Tenggara Tiur: Legenda Ile Mauraja, 27) Papua Barat: Asal Usul Burung Cenderawasih.

Keenampuluh dua cerita tersebut menjadi pusat analisis sekaligus menjadi gambaran dari cerita rakyat nusantara karena mewakili setiap wilayah di Indonesia, yaitu Barat, Tengah, dan Timur. Sesuai dengan tujuan penelitian, berikut dipaparkan mulamula gambaran arketipe peran Ibu dalam cerita rakyat nusantara dan dilanjutkan dengan kontribusi temuan tersebut dalam terapi lintas budaya.

\subsection{Arketipe peran Ibu dalam cerita rakyat Nusantara}

Arketipe oleh Jung (2014) didefinisikan sebagai bentuk dari ketaksadaran kolektif. Dengan kata lain, suatu komunitas budaya ataupun sosial memiliki satu pandangan bersama yang menjadi dasar bagi pengetahuan, nilai, dan perilaku masyarakatnya. Berbagai hal ini kemudian merupakan bentuk "mimpi" kolektif yang mengendap dalam produk budaya masyarakatnya. Dalam kultur masyarakat Nusantara, Ibu merupakan imajinasi kutlural yang menjadi gambaran dari sosok pelindung, pengayom, dan pemberi kehidupan manusia (Andalas, 2018). Karena dalam imajinasi kultural bangsa Nusantara, sosok Ibu menempati posisi yang sangat penting.

Dalam cerita rakyat Nusantara, gambaran tentang sosok Ibu dan perannya dalam alur pengisahan cukup banyak ditemui. Dalam pengisahannya, cukup banyak ditemukan arketipe peran Ibu. Berbagai arketipe yang ditemukan menunjukkan suatu bentuk oposisi biner antara gambaran Ibu yang baik (good mother) dan Ibu yang jahat (bad mother). Berbagai gambaran tentang arketipe peran Ibu dalam cerita rakyat Nusantara sebagai berikut.

\subsubsection{Ibu yang baik (Good Mother)}

Dari ke-62 cerita yang memiliki gambaran tentang relasi Ibu dan anak, 
terdapat 31 cerita yang menggambarkan mengenai arketipe peran Ibu yang baik.
Ketigapuluh cerita tersebut sebagai berikut.

Tabel 1. Cerita rakyat dengan pengggambaran arketipe peran Ibu baik

\begin{tabular}{|c|c|c|c|c|}
\hline No & Judul & Asal & Peristiwa dalam Cerita & Deskripsi Peran Ibu \\
\hline 1 & $\begin{array}{l}\text { Banta } \\
\text { Seudang }\end{array}$ & Aceh & $\begin{array}{c}\text { Ibu Banta merupakan sosok Ibu yang sangat sabar, } \\
\text { penyayang, dan penuh perjuangan demi masa depan Banta. } \\
\text { Hal ini tampak melalui tindakan Ibu Banta mengantarkan } \\
\text { anaknya ke Pak Ciknya (adik laki-laki suaminya yang } \\
\text { diangkat menjadi penerus kerajaan) agar menyekolahkan } \\
\text { Banta hingga dewasa. Berkat permohonan dan perjuangan } \\
\text { Ibu Banta, akhirnya Pak Ciknya yang kejam mau } \\
\text { menyekolahkan Banta. }\end{array}$ & $\begin{array}{l}\text { Sabar, penyayang, dan } \\
\text { selalu memperjuangkan } \\
\text { masa depan anaknya }\end{array}$ \\
\hline 2 & $\begin{array}{c}\text { Banta } \\
\text { Berensyah }\end{array}$ & Aceh & $\begin{array}{c}\text { Ibu Banta Berensyah adalah seorang Ibu yang selalu } \\
\text { bekerja keras untuk menghidupi anaknya. Ia tetap bekerja } \\
\text { walaupun terus dicaci maki oleh majikannya. }\end{array}$ & $\begin{array}{l}\text { Penyayang, pekerja } \\
\text { keras, dan bertanggung } \\
\text { jawab pada anak. }\end{array}$ \\
\hline 3 & Si Kepar & Aceh & $\begin{array}{l}\text { Ibu Kepar adalah seorang janda yang sangat kuat karena } \\
\text { mampu menghidupi anaknya sejak kecil hingga tumbuh } \\
\text { dewasa tanpa bantuan laki-laki. Ibu Kepar selalu bekerja } \\
\text { setiap hari demi menghidupi anaknya. }\end{array}$ & $\begin{array}{l}\text { Penuh perjuangan dan } \\
\text { tanggung jawab terhadap } \\
\text { anak. }\end{array}$ \\
\hline 5 & Si Baroar & $\begin{array}{l}\text { Sumatera } \\
\text { Utara }\end{array}$ & $\begin{array}{l}\text { Saua adalah seorang Ibu tiri Baroar yang sangat } \\
\text { menyayangi Baroar dengan sepenuh hati. Hal ini terlihat } \\
\text { ketika ia mati-matian memperjuangkan nyawa Baroar dari } \\
\text { kejaran para hulubalang istana yang hendak membunuh } \\
\text { Baroar. Ibu Saua tidak pernah menyerah berlari bersama } \\
\text { Baroar sampai akhirnya mereka berdua selamat. }\end{array}$ & $\begin{array}{l}\text { Penyayang. pantang } \\
\text { menyerah, dan } \\
\text { bertanggung jawab }\end{array}$ \\
\hline 6 & $\begin{array}{c}\text { Si Beru } \\
\text { Dayang } \\
\text { (Asal Mula } \\
\text { Padi) }\end{array}$ & $\begin{array}{l}\text { Sumatera } \\
\text { Utara }\end{array}$ & $\begin{array}{c}\text { Ibu Si Beru Dayang adalah seorang yang sangat } \\
\text { menyayangi anaknya. Oleh karena rasa sayangnya yang } \\
\text { begitu dalam pada Si Beru Dayang, Ibu ini bunuh diri } \\
\text { dengan menceburkan diri ke sungai karena kematian Si } \\
\text { Beru Dayang akibat kelaparan karena kampung mereka } \\
\text { dilanda kemarau berkepanjangan. }\end{array}$ & $\begin{array}{l}\text { Penyayang dan tidak } \\
\text { bisa hidup tanpa anak }\end{array}$ \\
\hline 7 & $\begin{array}{c}\text { Kisah } \\
\text { Pohon Enau }\end{array}$ & $\begin{array}{l}\text { Sumatera } \\
\text { Utara }\end{array}$ & $\begin{array}{l}\text { Sosok Ibu dalam cerita ini ialah Ibu dari } 2 \text { anak laki-laki } \\
\text { dan perempuan yang bernama Tare Iluh dan Beru Sibou. } \\
\text { Ibu diceritakan sebagai pekerja keras karena suaminya } \\
\text { meninggal. Ia harus menghidupi kedua anaknya. Namun } \\
\text { akhirnya ia juga meninggal karena terlalu lelah bekerja. }\end{array}$ & $\begin{array}{l}\text { Pekerja keras demi } \\
\text { menghidupi anak }\end{array}$ \\
\hline 8 & $\begin{array}{l}\text { Asal Mula } \\
\text { Nagari Koto } \\
\text { Nan Ampek } \\
\text { dan Koto } \\
\text { Nan Gadang }\end{array}$ & $\begin{array}{c}\text { Sumatera } \\
\text { Barat }\end{array}$ & $\begin{array}{c}\text { Sosok Ibu disini memiliki sifat yang pengertian kepada } \\
\text { anaknya. Hal ini terlihat ketika Ibu bertanya atas kesediaan } \\
\text { anaknya untuk dinikahkan dengan lelaki pilihannya. Sosok } \\
\text { Ibu memberikan peluang pada anak untuk memilih ataupun } \\
\text { menolak. }\end{array}$ & Pengertian terhadap anak \\
\hline 9 & $\begin{array}{l}\text { Bujang } \\
\text { Kirai yang } \\
\text { Pemberani }\end{array}$ & $\begin{array}{l}\text { Sumatera } \\
\text { Barat }\end{array}$ & $\begin{array}{c}\text { Ibu Siti Asanah adalah seorang Ibu yang sangat arif dan } \\
\text { bijaksana pada anak laki-lakinya bernama Bujang Kirai, } \\
\text { bahkan ia sangat peduli pada adik laki-lakinya bernama } \\
\text { Sutan Panduko. Hal ini tergambar melalui tindakan Ibu Siti } \\
\text { Asanah yang selalu mengajarkan aturan agama dan adat } \\
\text { serta mengajarkan ilmu bela diri pada anak dan adik laki- } \\
\text { lakinya. Berkat didikan Ibunya, Bujang Kirai tumbuh } \\
\text { menjadi pemuda yang perkasa dan sakti sehingga dapat } \\
\text { menyelamatkan pamannya. }\end{array}$ & $\begin{array}{l}\text { Arif, baik, penyayang } \\
\text { dan peduli }\end{array}$ \\
\hline 10 & $\begin{array}{l}\text { Hang Tuah } \\
\text { Kesatria } \\
\text { Melayu }\end{array}$ & Riau & $\begin{array}{l}\text { Dang Ratna diceritakan sebagai Ibu angkat Hang Tuah } \\
\text { yang sangat baik dan sangat sayang pada Hang Tuah. Hal } \\
\text { ini terlihat dari tindakannya yang merawat Hang Tuah } \\
\text { dengan sepenuh hati ketika Hang Tuah diusir dari kerajaan } \\
\text { karena difitnah oleh prajurit dan pegawai kerajaan. }\end{array}$ & $\begin{array}{l}\text { Penyayang dan peduli } \\
\text { walaupun kepada anak } \\
\text { tiri }\end{array}$ \\
\hline 11 & $\begin{array}{l}\text { Dang } \\
\text { Gedunai } \\
\text { (Asal Mula } \\
\text { Naga di } \\
\text { Laut Lepas) }\end{array}$ & Riau & $\begin{array}{l}\text { Sosok Ibu disini ialah Ibu dari seorang anak laki-laki yang } \\
\text { sangat keras kepala bernama Dang Gedunai. Ibu sangat } \\
\text { menyayangi dan peduli pada keselamatan Dang Gedunai. } \\
\text { Suatu ketika saat Dang Gedunai hendak makan telur naga, } \\
\text { Ibu terus menasihati Dang Gedunai agar tidak memakan } \\
\text { telur tersebut. Namun, nasihatnya tak dihiraukan Dang } \\
\text { Gedunai. Akhirnya Dang Gedunai berubah menjadi naga } \\
\text { setelah memakan telur tersebut. }\end{array}$ & $\begin{array}{l}\text { Penyayang, peduli dan } \\
\text { sabar pada tingkah laku } \\
\text { anak }\end{array}$ \\
\hline
\end{tabular}




\begin{tabular}{|c|c|c|c|c|}
\hline 12 & $\begin{array}{l}\text { Si Bujang } \\
\text { (asal mula } \\
\text { burung } \\
\text { punai) }\end{array}$ & Riau & $\begin{array}{l}\text { Emak dalam cerita ini ialah Ibu Bujang yang selalu bekerja } \\
\text { keras demi menghidupi anaknya dengan harapan agar } \\
\text { anaknya dapat tumbuh jadi pribadi yang baik. }\end{array}$ & Pekerja keras \\
\hline 13 & $\begin{array}{c}\text { Baginde } \\
\text { Lubuk Gong }\end{array}$ & $\begin{array}{l}\text { Sumatera } \\
\text { Selatan }\end{array}$ & $\begin{array}{c}\text { Ibu adalah Ibu dari Putri Lubuk Gong yang sangat } \\
\text { menyayangi putrinya. Namun ia tidak dapat berbuat apa- } \\
\text { apa ketika mendapati anaknya tewas dIbunuh, melainkan } \\
\text { hanya bisa menangis. }\end{array}$ & Baik dan penyayang \\
\hline 14 & $\begin{array}{l}\text { Si Gulap } \\
\text { yang Sabar }\end{array}$ & Bengkulu & $\begin{array}{c}\text { Janda adalah Ibu yang penyayang pada ketujuh anaknya } \\
\text { saja dan selalu mendidik anak dengan baik. Ia menginsirasi } \\
\text { anaknya untuk berjuang mengubah garis kemiskinan } \\
\text { keluarganya. }\end{array}$ & $\begin{array}{l}\text { Baik hati dan mendidik } \\
\text { anak dengan baik. }\end{array}$ \\
\hline 15 & $\begin{array}{c}\mathrm{Si} \\
\text { Kelingking }\end{array}$ & Jambi & $\begin{array}{l}\text { Ibu adalah Ibu kelingking yang pada mulanya telah } \\
\text { menikah berpuluh tahun belum dikaruniai anak. Ia bersama } \\
\text { sang suami berdoa terus pada Tuhan agar diberi anak } \\
\text { walaupun sebesar kelingking. Akhirnya doanya dikabulkan, } \\
\text { mereka memiliki anak sebesar kelingking. Walaupun } \\
\text { demikian mereka tetap menyayangi kelingking dengan } \\
\text { sepenuh hati. }\end{array}$ & $\begin{array}{l}\text { Sabar, penyayang, dan } \\
\text { beryukur/menerima sang } \\
\text { anak apa adanya }\end{array}$ \\
\hline 16 & $\begin{array}{l}\text { Sang } \\
\text { Kabelah }\end{array}$ & Lampung & $\begin{array}{c}\text { Ibu adalah sosok yang sangat sabar walaupun puluhan } \\
\text { tahun tidak dikaruniai anak. Setelah suaminya berdoa } \\
\text { meminta anak setengah badan pada Tuhan akhirnya Ibu } \\
\text { melahirkan anak setengah badan diberi nama Kabelah. } \\
\text { Walaupun demikian Ibu menyayangi, menerima, dan } \\
\text { merawat anaknya dengan setulus hati. }\end{array}$ & $\begin{array}{l}\text { Sabar dan menerima } \\
\text { anak apa adanya }\end{array}$ \\
\hline 17 & $\begin{array}{l}\text { Si Bugu } \\
\text { yang Pandir }\end{array}$ & Lampung & $\begin{array}{c}\text { Ibu Bugu selalu mengajarkan kebaikan dan menyuruh } \\
\text { Bugu segera mencari pendamping hidup. (ragu karena } \\
\text { hanya dijelaskan seperti ini) }\end{array}$ & $\begin{array}{l}\text { Baik hati (tidak terlalu } \\
\text { digambarkan) }\end{array}$ \\
\hline 18 & $\begin{array}{l}\text { Bujang } \\
\text { Katak }\end{array}$ & $\begin{array}{l}\text { Bangka } \\
\text { Belitung }\end{array}$ & $\begin{array}{l}\text { Perempuan tua adalah seorang Ibu angkat bujang katak. } \\
\text { Hal ini terjadi karena perempuan tua hidup sebatang kara } \\
\text { dan berdoa pada Tuhan agar diberi anak walaupun } \\
\text { berbentuk katak. Doa tersebut dikabulkan dan perempuan } \\
\text { tua memiliki anak berbentuk katak yang disebut Bujang } \\
\text { Katak. Meski demikian perempuan tua sangat menyayangi } \\
\text { dan merawat Bujang Katak dengan sepenuh hati. Berkat } \\
\text { kesabarannya itu Bujang Katak berubah menjadi pria gagah } \\
\text { dan tampan serta menikah dengan putri raja. }\end{array}$ & $\begin{array}{l}\text { Penyayang, sabar, dan } \\
\text { menerima anak apa } \\
\text { adanya }\end{array}$ \\
\hline 19 & Si Pitung & $\begin{array}{c}\text { DKI } \\
\text { Jakarta }\end{array}$ & $\begin{array}{c}\text { Ibu Pinah adalah Ibu dari Si Pitung yang sangat } \\
\text { menyayanginya. Bahkan saat Pitung hendak melawan } \\
\text { Babah Liem yang jahat di kampung mereka, Ibu Pinah } \\
\text { sangat melarang Pitung karena khawatir akan keselamatan } \\
\text { anaknya. Akan tetapi Si Pitung tetap pergi dan ia tewas } \\
\text { tertembak. } \\
\end{array}$ & $\begin{array}{c}\text { Penyayang dan peduli } \\
\text { pada anak }\end{array}$ \\
\hline 20 & $\begin{array}{c}\text { Putri } \\
\text { Kandita }\end{array}$ & $\begin{array}{l}\text { Jawa } \\
\text { Barat }\end{array}$ & $\begin{array}{c}\text { Ibu adalah seorang permaisuri dan memiliki banyak anak. } \\
\text { Namun yang baik hanyalah satu yaitu Putri Kandita. Sosok } \\
\text { Ibu memiliki sifat yang sangat sabar dan pasrah walaupun } \\
\text { didukunkan oleh anaknya yang lain hingga tubuhnya } \\
\text { dipenuhi penyakit kusta hingga tewas. }\end{array}$ & $\begin{array}{l}\text { Sabar dan pasrah } \\
\text { terhadap kelakuan anak }\end{array}$ \\
\hline 21 & $\begin{array}{l}\text { Dayang } \\
\text { Sumbi }\end{array}$ & $\begin{array}{l}\text { Jawa } \\
\text { Barat }\end{array}$ & $\begin{array}{l}\text { Dayang Sumbi adalah Ibu dari Sangkuriang yang hendak } \\
\text { dinikahi anaknya sendiri. Setelah mengetahui bahwa } \\
\text { Sangkuriang adalah anaknya, Dayang Sumbi } \\
\text { menggagalkan pernikahan mereka dengan syarat dIbuatkan } \\
\text { bendungan dan perahu dalam waktu satu malam. Karena } \\
\text { kecerdikan Dayang Sumbi, Sangkuriang gagal memenuhi } \\
\text { persyaratannya dan mereka tidak jadi menikah. }\end{array}$ & Penyayang \\
\hline 22 & Jaka Tarub & $\begin{array}{c}\text { Jawa } \\
\text { Tengah } \\
\end{array}$ & $\begin{array}{c}\text { Sangat menyayangi dan merawat Jaka Tarub dengan } \\
\text { sepenuh hati }\end{array}$ & Baik dan penyayang \\
\hline 23 & Timun Mas & $\begin{array}{l}\text { Jawa } \\
\text { Tengah }\end{array}$ & $\begin{array}{c}\text { Mbok Srini adalah seorang Ibu yang sangat menyayangi } \\
\text { Timun Mas. Ia sampai mengingkari janjinya pada raksasa } \\
\text { yaitu ketika timun mas dewasa akan diserahkan ke raksasa, } \\
\text { namun Timun Mas justru tidak diserahkan. Karena hal } \\
\text { tersebut, Mbok Srini bekerja keras melakukan segala cara } \\
\text { agar raksasa tidak mengambil timun mas darinya. }\end{array}$ & $\begin{array}{l}\text { Penyayang, kerja keras, } \\
\text { dan ingkar janji pada } \\
\text { raksasa karena untuk } \\
\text { menyelamatkan anaknya }\end{array}$ \\
\hline 24 & $\begin{array}{l}\text { Legenda } \\
\text { Rawa } \\
\text { Pening }\end{array}$ & $\begin{array}{l}\text { Jawa } \\
\text { Tengah }\end{array}$ & $\begin{array}{c}\text { Nyai Selakanta adalah Ibu yang sangat menyayangi } \\
\text { anaknya bernama Baru Klunthing dan menerima apa } \\
\text { adanya walaupun anaknya seekor naga. Ia yakin suatu saat }\end{array}$ & $\begin{array}{l}\text { Penyayang dan } \\
\text { menerima anaknya apa } \\
\text { adanya }\end{array}$ \\
\hline
\end{tabular}




\begin{tabular}{|c|c|c|c|c|}
\hline & & & $\begin{array}{c}\text { anaknya dapat berubah wujud menjadi manusia. Setelah } \\
\text { bertapa di bukit, Baru Klinthing berubah menjadi manusia. }\end{array}$ & \\
\hline 25 & $\begin{array}{c}\text { Baginde } \\
\text { Lubuk Gong }\end{array}$ & $\begin{array}{l}\text { Sumatera } \\
\text { Selatan }\end{array}$ & $\begin{array}{l}\text { Ibu adalah Ibu dari Putri Lubuk Gong yang sangat } \\
\text { menyayangi putrinya. Namun ia tidak dapat berbuat apa- } \\
\text { apa ketika mendapati anaknya tewas dIbunuh, melainkan } \\
\text { hanya bisa menangis. }\end{array}$ & $\begin{array}{l}\text { Baik, penyayang dan } \\
\text { tidak dapat berbuat apa- } \\
\text { apa }\end{array}$ \\
\hline 26 & $\begin{array}{l}\text { Legenda } \\
\text { Tanjung } \\
\text { Lesung }\end{array}$ & Banten & $\begin{array}{c}\text { Ibunda dari Sri Poh Haci adalah seorang Ibu yang sangat } \\
\text { menyayangi anaknya. Ia sempat menasihati Sri Poh Haci } \\
\text { agar tidak menikah dengan pemuda keras kepala bernama } \\
\text { Raden Budog, namun nasihatnya dihiraukan putrinya. } \\
\text { Alhasil malapetaka menimpa putrinya karena tetap } \\
\text { menikah dengan Raden Budog. }\end{array}$ & $\begin{array}{l}\text { Penyayang dan peduli } \\
\text { pada anak }\end{array}$ \\
\hline 27 & Palui & $\begin{array}{c}\text { Kalimanta } \\
\text { n Tengah }\end{array}$ & $\begin{array}{c}\text { Ibu sangat menyayangi Palui dan menuruti permintaan } \\
\text { Palui }\end{array}$ & Penyayang pada anak \\
\hline 28 & Ratu Adioa & $\begin{array}{l}\text { Sulawesi } \\
\text { Utara }\end{array}$ & $\begin{array}{c}\text { Ibu Adioa selalu mengajarkan kebaikan pada Adioa. Beliau } \\
\text { selalu mendukung tindakan baik Adioa. Bahkan sang Ibu } \\
\text { mengajari Adioa menjawab teka-teki demi menyelamatkan } \\
\text { kampung mereka. }\end{array}$ & $\begin{array}{l}\text { Penyayang dan selalu } \\
\text { mendukung anaknya }\end{array}$ \\
\hline 29 & $\begin{array}{l}\text { Asal Mula } \\
\text { Ikan } \\
\text { Duyung } \\
\end{array}$ & $\begin{array}{l}\text { Sulawesi } \\
\text { Tengah }\end{array}$ & $\begin{array}{l}\text { Ibu adalah jelmaan ikan duyung yang sabar menghadapi } \\
\text { sikap kasar suaminya. Ia juga sangat menyayangi ketiga } \\
\text { anaknya. Bahkan ia rela dihukum suaminya demi anaknya. }\end{array}$ & $\begin{array}{l}\text { Penyayang, sabar, } \\
\text { melakukan apapun demi } \\
\text { kebaikan anak } \\
\end{array}$ \\
\hline 30 & $\begin{array}{l}\text { Limonu } \\
\text { yang } \\
\text { Perkasa }\end{array}$ & Gorontalo & Sangat menyayangi anaknya & $\begin{array}{c}\text { Penyayang, bertanggung } \\
\text { jawab }\end{array}$ \\
\hline 31 & $\begin{array}{l}\text { Legenda Ile } \\
\text { Mauraja }\end{array}$ & $\begin{array}{l}\text { Nusa } \\
\text { Tenggara } \\
\text { Timur }\end{array}$ & Sangat menyayangi anaknya & Penyayang \\
\hline
\end{tabular}

Tabel 1 merupakan gambaran mengenai 31 cerita rakyat yang menggambarkan arketipe peran Ibu yang baik. Ke-31 cerita ini berasal dari 19 provinsi. Dalam cerita-cerita tersebut, tergambarkan imajinasi mengenai arketipe peran Ibu. Bagaimana posisi Ibu dalam kultur masyarakat di berbagai wilayah tersebut tergambarkan dalam cerita.

Dalam arketipe peran Ibu yang ditemukan dalam cerita rakyat Nusantara, gambaran yang ada menunjukkan karakter maskulin dari sosok Ibu yang memawakili mother animus. Mother animus muncul sebagai sisi maskulinitas perempuan yang lahir atas dasar dorongan tak sadar untuk merespon berbagai hal yang terjadi di sekitarnya. Terdapat 5 sisi maskulin Ibu yang muncul pada ke-31 cerita, yaitu berkorban demi anak, bekerja keras demi anak, pengasuh, pelindung, dan guru.

Pertama, sifat berkorban demi anak ditemukan pada cerita berjudul "Banta Seudang" dari Aceh dan "Asal Mula Ikan Duyung" dari Sulawesi Tengah. Tokoh Ibu pada kedua cerita bukanlah seorang pahlawan. Melalui kecintaannya pada anaknya, Ibu mengekpresikannya melalui perjuangan yang ditunjukan untuk keberhasilan anaknya. Pada cerita "Banta Seudang", Ibu harus mengesampingkan rasa takut dan egonya untuk memohon kepada Pak Ciknya yang terkenal keras dan kejam agar anaknya dapat disekolahkan. Selain itu pada cerita "Asal Mula Ikan Duyung", Ibu mengekspresikan rasa kasih sayangnya dengan rela dihukum oleh suaminya demi anaknya. Dengan kata lain, pada kedua cerita tersebut tampak bahwa mother animus pengorbanan Ibu demi anak dieskpresikan secara terbuka dan langsung seperti yang digambarkan pada contoh karakter maskulin Ibu pada kedua cerita.

Kedua, sifat bekerja keras demi anak ditemukan pada cerita "Banta Barensyah" dari Aceh, "Si Kepar" dari Aceh, "Kisah Pohon Enau" dari Sumatera Utara, dan "Si Bujang" dari Riau. Pada keempat cerita, sisi maskulin Ibu digambarkan melalui gambaran bekerja keras demi keberlangsungan hidup anaknya. Sebagai contoh, pada cerita Banta Barensyah, sosok Ibu digambarkan sebagai pekerja keras meskipun selalu mendapat caci maki dari majikannya. Segalanya dilakukan untuk memenuhi kebutuhan hidup anaknya.

Ketiga, sifat pengasuh (nurturing) ditemukan pada cerita "Si Beru Dayang" 
dari Sumatera Utara, "Hang Tuah Kesatria Melayu" dari Riau, "Baginde Lubuk Gong" dari Sumatera Selatan, "Si Kelingking" dari Jambi, "Sang Kabelah" dari Lampung, "Bujang Katak" dari Bangka Belitung, "Si Pitung" dari DKI Jakarta, "Putri Kandita" dari Jawa Barat, "Jaka Tarub" dari Jawa Tengah, "Legenda Rawa Pening" dari Jawa Tengah, "baginde Lubuk Gong" dari Sumatera Selatan, "Palui" dari Kalimantan Tengah, "Limonu yang Perkasa" dari Gorontalo, dan "Lgenda Ile Mauraja" dari Nusa Tenggara Timur. Pada cerita-cerita ini, Ibu merupakan sosok pengasuh yang sangat mencintai anak-anaknya. Dengan rasa penuh kasih sayang, sisi maskulin dari Ibu tampak dari usahanya dalam menjaga anak-anaknya dari segala macam bahaya. Sebagai contoh, pada cerita "hang Tuah Kesatria Melayu", meskipun sosok Ibu adalah Ibu angkat, tetapi ia sangat sayang kepada hangtuah. Hal ini digambarkan melalui tindakannya merawat Hang Tuah sepenuh hati ketika Hang Tuah diusir dari kerajaan karena difitnah oleh prajurit dan pegawai kerajaan. Pada ceritacerita ini, bentuk pengasuhan penuh kasih sayang dikespresikan secara terbuka dan langsung, alih-alih secara introvert.

Keempat, yaitu sifat pelindung (selfless). Sifat ini ditemukan pada cerita "Si Baroar" dari Sumatera Utara dan "Timun Mas" dari Jawa Tengah. Sisi maskulin Ibu ditunjukkan pada upaya seorang Ibu untuk melindungi anak-anaknya dari berbagai ancaman. Misalnya, pada cerita Timun Mas, Ibu mengingkari janjinya kepada raksasa karena Ibu tahu raksasa akan memakan anak semata wayangnya tersebut.

Kelima, sifat Ibu ditunjukkan melalui kebijaksanaannya dalam mendidik anak. Ibu menjadi guru yang mengarahkan dan membimbing anak-anaknya. Pada cerita rakyat Nusantara sifat maskulin ini ditemukan pada cerita "Asal Mula Nagari Koto Nan Ampek dan Koto Nan Gadang" dari Sumatera Barat, "Bujang Kirai yang Pemberani" dari Sumatera Barat, "Dang Gedunai" dari Riau, "Si Gulap yang Sabar" dari Bengkulu, "Si Bungu yang Pandir" dari Lampung, "Legenda Tanjung Lesung" dari
Banten, dan "Ratu Adioa" dari Sulawesi Utara. Pada cerita-cerita tersebut, Ibu menjadi sosok yang mengarahkan dan memberikan pelajaran hidup kepada anakanaknya. Sebagai contoh, pada cerita "Ratu Adioa", Ibu selalu mengajarkan kebaikan kepada anaknya. Bahkan Ibu mengajari Adioa menjawa teka-teki demi menyelamatkan kampung mereka.

Kelima, bentuk mother animus pada cerita rakyat Nusantara tersebut memperlihatkan sisi maskulinitas yang ada pada diri seorang Ibu. Dalam hubungan Ibuanak, imajinasi kolektif masyarakat Nusantara dalam menggambarkan peran baik seorang Ibu tergambarkan dalam bentuk 1) Ibu akan berkorban untuk anaknya, 2) Ibu bekerja keras untuk anaknya, 3) Ibu mengayomi (mengasihi) anaknya, 4) Ibu melindungi anaknya dari berbagai ancaman, dan 5) Ibu menjadi guru bagi anak-anaknya. Kelima peran ini merupakan gambaran bagaimana imajinasi kolektif masyarakat Nusantara dalam mencitrakan sosok Ibu yang baik bagi anakanaknya. Kelima hal ini merupakan gambaran mendasar yang menjadi citra budaya yang melembaga di dalam ceritacerita rakyat Nusantara dan diwariskan antargenerasi.

Berbagai gambaran mengenai peran Ibu tersebut selaras dengan hasil penelitian yang dilakukan oleh Lestari et al., (2018) dan Putra \& Alias (2018) bahwa dalam cerita rakyat Ibu sering digambarkan sebagai sosok pengayom dan panutan bagi anakanaknya karena memiki nilai yang baik. Bahkan dalam kultur imajinasi kolektif Nusantara, Ibu sering menempati posisi yang penting dan menjadi personifikasi sosok simbolis pemberi kehidupan, kesejahteraan, dan perlindungan manusia baik di darat maupun di laut (Andalas, 2018).

\subsubsection{Ibu yang buruk (Bad Mother)}

Dari ke-62 cerita yang memiliki gambaran tentang relasi Ibu dan anak, terdapat 17 cerita yang menggambarkan mengenai arketipe peran Ibu yang buruk. 
Ketujuh belas cerita tersebut sebagai berikut.

Tabel 2 Cerita rakyat dengan pengggambaran arketipe peran Ibu yang buruk

\begin{tabular}{|c|c|c|c|c|}
\hline No & Judul & Asal & Peristiwa dalam Cerita & $\begin{array}{c}\text { Deskripsi Peran } \\
\text { Ibu }\end{array}$ \\
\hline 1 & $\begin{array}{l}\text { Tujuh anak } \\
\text { laki-laki }\end{array}$ & Aceh & $\begin{array}{c}\text { Ibu Tujuh anak laki-laki adalah seorang yang } \\
\text { memiliki sifat jahat karena tega menelantarkan } \\
\text { ketujuh anak laki-lakinya di tengah hutan. Hal } \\
\text { tersebut ia lakukan karena tidak mampu } \\
\text { menghidupi ketujuh anaknya akibat desanya } \\
\text { dilanda kemarau berkepanjangan, sehingga } \\
\text { membuat hasil pertaniannya buruk. }\end{array}$ & Menelantarkan anak \\
\hline 2 & $\begin{array}{l}\text { Mentiko } \\
\text { Betuah }\end{array}$ & Aceh & $\begin{array}{l}\text { Ibu Rohib selalu memanjakan anaknya dengan } \\
\text { memenuhi segala keinginan Rohib hingga } \\
\text { Rohib tumbuh menjadi pribadi yang gagal } \\
\text { menyelesaikan sekolahnya. Meskipun } \\
\text { demikian, Ibu Rohib tetap membela anaknya } \\
\text { agar tidak dihukum mati oleh suaminya dengan } \\
\text { mencarikan solusi agar anaknya diberi } \\
\text { kesempatan untuk menjadi bagian dari kerajaan } \\
\text { dengan cara merantau untuk menjadi pedagang. }\end{array}$ & $\begin{array}{c}\text { Penyayang dan } \\
\text { melakukan segala } \\
\text { cara demi kesenangan } \\
\text { dan keselamatan } \\
\text { anaknya. }\end{array}$ \\
\hline 3 & $\begin{array}{c}\text { Batu Gantung } \\
\text { (Legenda } \\
\text { Kota Parapat) }\end{array}$ & Sumatera Utara & $\begin{array}{l}\text { Ibu Seruni adalah seorang Ibu yang tidak mau } \\
\text { memahami keinginan anaknya, sebab ia } \\
\text { menjodohkan anaknya (Seruni) dengan laki- } \\
\text { laki yang tidak dicintai anaknya. Akibat } \\
\text { perjodohan tersebut, Seruni bunuh diri dan } \\
\text { terperosok ke dalam lubang besar hingga } \\
\text { berubah wujud menjadi batu menggantung. }\end{array}$ & Egois \\
\hline 4 & $\begin{array}{l}\text { Kisah Putri } \\
\text { Ular }\end{array}$ & Sumatera Utara & $\begin{array}{l}\text { Ibu Putri adalah seorang yang bersifat terlalu } \\
\text { menuntut pada anaknya (Putri). Hal ini terlihat } \\
\text { ketika ia bersama suaminya sangat menekan } \\
\text { Putri untuk menjaga diri sebaik mungkin agar } \\
\text { paras cantiknya tetap terjaga. Hal tersebut } \\
\text { membuat Putri merasa sangat terbebani. Hal ini } \\
\text { tampak ketika hidung Putri terkena ranting ia } \\
\text { merasa sangat bersalah dan menganggap hal } \\
\text { tersebut fatal. Akibat hal tersebut, Putri } \\
\text { meminta doa pada Tuhan agar ia dihukum. } \\
\text { Akhirnya Putri berubah wujud menjadi ular. }\end{array}$ & Penuntut \\
\hline 5 & $\begin{array}{l}\text { Asal Mula } \\
\text { Sungai } \\
\text { Ombilin dan } \\
\text { Danau Si }\end{array}$ & Sumatera Barat & $\begin{array}{c}\text { Sosok Ibu disini ialah Ibu dari seorang anak } \\
\text { bernama Indra. Ibu memiliki sifat yang licik } \\
\text { dan tega pada anaknya sendiri. Ibu selalu } \\
\text { memperlakukan Indra dengan keras yaitu } \\
\text { menyuruh Indra mencari makanan di hutan dan } \\
\text { di laut seharian serta tidak memperbolehkan } \\
\text { pulang jika tidak mendapat makanan. Bahkan } \\
\text { sang Ibu juga tega tidak membagi makanan } \\
\text { dengan anaknya walaupun ia tahu anaknya } \\
\text { sangatlah kelaparan. } \\
\end{array}$ & Kejam \\
\hline
\end{tabular}

Ibu adalah seorang Ibu dari Tan Talanai.

Awalnya ia dan suaminya sangat menginginkan keturunan karena sudah lama menikah. Namun setelah melahirkan Tan Talanai, ada tabib yang mengatakan bahwa anak tersebut membawa

Membunuh Anak malapetaka bagi kerajaan. Akhirnya raja dan istrinya (ayah Ibu Tan Talanai) membuang Tan ke laut.

\begin{tabular}{|c|c|c|c|c|}
\hline 7 & $\begin{array}{c}\text { Putri Rainun } \\
\text { dan Rajo } \\
\text { Mudo }\end{array}$ & Jambi & $\begin{array}{c}\text { Ibu Putri Rainun adalah seorang Ibu yang egois } \\
\text { karena telah mamaksan Putri Rainun untuk } \\
\text { menikah dengan lelaki kaya pilihannya. Setelah } \\
\text { menikah dengan lelaki pilihan Ibunya, Putri } \\
\text { Rainun bunuh diri. }\end{array}$ & Egois \\
\hline 8 & Si Bungsu & Lampung & $\begin{array}{l}\text { Ibu disini memiliki anak berjumlah tujuh. Ibu } \\
\text { dan suaminya merasa tidak nyaman dengan } \\
\text { ketujuh anaknya yang setiap kali ayah dan Ibu }\end{array}$ & Serakah \\
\hline
\end{tabular}




\begin{tabular}{|c|c|c|c|c|}
\hline & & & $\begin{array}{l}\text { makan, ketujuh anaknya ikut makan. Hal ini } \\
\text { membuat ayah dan Ibu tidak kenyang. } \\
\text { Akhirnya ayah dan Ibu membuang ketujuh } \\
\text { anaknya ke hutan. } \\
\end{array}$ & \\
\hline 9 & Unang Batin & Lampung & $\begin{array}{c}\text { Ibu disini adalah Ibu dari pemuda bernama } \\
\text { Unang Batin yang selalu menuntut anaknya } \\
\text { untuk menjadi pendekar sakti mandraguna } \\
\text { hingga anaknya disuruh berkelana untuk } \\
\text { menuntut ilmu ke berbagai tempat }\end{array}$ & Penuntut \\
\hline 10 & Si Kelingking & Bangka Belitung & $\begin{array}{l}\text { Ibu adalah Ibu dari si kelingking. Awalnya Ibu } \\
\text { dan suaminya tidak memiliki anak selama } \\
\text { puluhan tahun, namun setelah berdoa mereka } \\
\text { dikaruniai si kelingking yang tubuhnya kecil } \\
\text { tapi makannya banyak hingga membuat orang } \\
\text { tuanya merasa kesal dan berniat } \\
\text { membunuhnya. Rencana jahat Ibu kelingking } \\
\text { diurungkan karena tahu bahwa kelingking } \\
\text { mampu bekerja berat sehingga dapat membantu } \\
\text { memenuhi kebutuhan hidup keluarganya. }\end{array}$ & Kejam \\
\hline 11 & $\begin{array}{c}\text { Bawang } \\
\text { Merah dan } \\
\text { Bawang Putih }\end{array}$ & Yogyakarta & $\begin{array}{l}\text { Mbok Randha selalu memarahi bawang putih } \\
\text { dan memperlakukannya dengan kasar. Bahkan } \\
\text { seluruh pekerjaan rumah diserahkan pada } \\
\text { bawang putih. Mbok Randha juga sangat kejam } \\
\text { karena tega memberi makan sekali saja dalam } \\
\text { waktu sehari pada bawang putih. }\end{array}$ & Kejam \\
\hline 12 & $\begin{array}{l}\text { Ande-ande } \\
\text { Lumut }\end{array}$ & Jawa Timur & $\begin{array}{l}\text { Nyai Intan adalah Ibu tiri Klenting Kuning } \\
\text { yang sangat jahat, pemarah, dan kasar } \\
\text { memperlakukan Klenting Kuning dengan } \\
\text { semena-mena. semua pekerjaan rumah } \\
\text { diserahkan ke Klenting Kuning. }\end{array}$ & Kejam \\
\hline 13 & $\begin{array}{l}\text { Jaka Seger } \\
\text { dan Rara } \\
\text { Anteng }\end{array}$ & Jawa Timur & $\begin{array}{l}\text { Rara Anteng adalah istri Jaka Seger yang tak } \\
\text { kunjung memiliki anak. Setelah berdoa, mereka } \\
\text { diberi anak sejumlah } 25 \text { namun Jaka Seger janji } \\
\text { akan mengorbankan satu anaknya ke Gunung } \\
\text { Bromo. Janji tersebut ditepati. Rara Anteng } \\
\text { sebagai Ibu, ikhlas mengorbankan anaknya } \\
\text { demi memenuhi janji suaminya. }\end{array}$ & Membunuh Anak \\
\hline 14 & $\begin{array}{c}\text { Legenda Pesut } \\
\text { Mahakam }\end{array}$ & Kalimantan Timur & $\begin{array}{c}\text { Ibu tiri dari anak laki-laki dan perempuan } \\
\text { sangat licik pada kedua anak tirinya tersebut. } \\
\text { Bahkan Ibu tiri sampai hati menyiksa kedua } \\
\text { anaknya setiap hari. } \\
\end{array}$ & Kejam \\
\hline 15 & $\begin{array}{l}\text { Sesentola dan } \\
\text { Burung } \\
\text { Garuda }\end{array}$ & Sulawesi Tengah & $\begin{array}{c}\text { Ibu adalah seorang yang sangat licik pada } \\
\text { anaknya. Ia tidak tahan dengan kelakuan } \\
\text { anaknya bernama Sesentola yang setiap hari } \\
\text { menghabiskan makan banyak. Karena itulah } \\
\text { Ibu berniat melenyapkan nyawa anak } \\
\text { kandungnya sendiri. } \\
\end{array}$ & Membunuh Anak \\
\hline 16 & La Upe & Sulawesi Selatan & $\begin{array}{c}\text { I Ruga adalah Ibu tiri dari La Upe yang sangat } \\
\text { kejam dan kasar. Ia seringkali menyuruh La } \\
\text { Upe bekerja dan memancing ikan di sungai. } \\
\text { Jika La Upe tidak membawa pulang makanan, } \\
\text { ia akan disiksa. }\end{array}$ & Kejam \\
\hline 17 & Cengnge' & Sulawesi Barat & $\begin{array}{l}\text { Seorang Ibu yang tega membuang anak } \\
\text { kandung perempuannya karena suaminya } \\
\text { hanya menginginkan anak laki-laki }\end{array}$ & Licik \\
\hline
\end{tabular}

Tabel 2 merupakan gambaran arketipe peran Ibu yang buruk dalam cerita rakyat Nusantara. Ketujuh belas cerita tersebut menggambarkan peran-peran buruk Ibu dalam hubungannya dengan anak. Arketipe peran Ibu buruk yang terdapat dalam cerita rakyat Nusantara, yaitu 1) menelantarakan anak, 2) egois, 3) kejam, 4) serakah, dan 5) tega membunuh anak sendiri.

Pertama, arketipe peran Ibu yang menelantarkan anak ditemui dalam beberapa cerita, seperti “Tujuh Anak Laki-Laki” dari Aceh dan. Pada cerita "Tujuh Anak LakiLaki", sosok Ibu menelantarkan ketujuh 
anaknya di hutan karena ia sudah tidak sanggup lagi untuk memberinya makan. Hal ini memperlihatkan sifat keputusasaan seorang Ibu yang lari dari tanggung jawab. Begitupun dalam cerita "Si Bungsu" karena cerita ini memiliki motif penceritaan yang sama dengan cerita "Tujuh Anak LakiLaki”.

Kedua, arketipe peran Ibu yang egois ditemukan pada cerita "Mentiko betuah" dari Aceh, "Batu Gantung (Legenda Kota Parapat)" dari Sumatera Utara dan "Putri Rainun dan Rajo Mudo" dari Jambi. Ketiga, arketipe peran Ibu yang kejam ditemukan pada cerita "Asal Mula Sungai Ombilin dan Danau Si" dari Sumatera Barat, "Si Kelingking" dari Bangka Belitung, "Andeande Lumut" dari Jawa Timur, "Legenda Pesut Mahakam" dari Kalimantan Timur, dan "La Upe" dari Sumatera Selatan, "Bawang Merah dan Bawa Putih" dari Jawa Timur. Keempat, arketipe peran Ibu yang serakah ditemukan pada cerita "Si Bungsu" dari Lampung. Kelima, arketipe peran Ibu yang ditemukan adalah tega "membunuh anak" kandung. Arketipe ini ditemukan pada cerita "Tan Talanai" dari Jambi, "Jaka Seger dan Rara Anteng" dari Jawa Timur, "Sesentola dan Burung Garuda" dari Sulawesi Tengah.

Dalam cerita-cerita tersebut terdapat gambaran imajinasi kolektif masyarakat Nusantara mengenai sosok Ibu yang memilki peran buruk (jahat). Berbagai gambaran tersebut, seperti tindakan membunuh anak dilakukan karena adanya unsur paksaan yang menyebabkan diri Ibu tidak memiliki pilihan. Berbagai gambaran ini merupakan arketipe universal yang ada pada diri Ibu yang jahat yang juga ditemukan dalam cerita-cerita rakyat di negara lain (Diala-Ogamba, 2015; Johns, 2004; Soenarto \& Tjahjani, 2019). Hal yang menjadikan berbeda dalam cerita rakyat nusantara adalah peran buruk Ibu muncul melalui ketidakpuasan secara individu pada diri Ibu ataupun pengaruh dari pihak lain, seperti tokoh lain ataupun makhluk supernatural.

Jika diperhatikan secara seksama, arketipe peran Ibu dalam hubunganya dengan anak tergabarkan dalam persofinikasi mulai dari hal yang bersifat personal berasal dari diri sendiri (egois) hingga tega membunuh anak sendiri. Gambaran mengenai sosok Ibu yang hingga tega membunuh anak sendiri memperlihatkan oposisi biner yang sangat tajam dari gambaran arketipe peran Ibu yang baik (Abrams, 2021). Gambaran-gambaran tersebut merupakan wujud dari ego Ibu dalam imajinasi kultural masyarakat Nusantara.

\subsubsection{Peran Ibu yang bertransformasi}

Dari ke-62 cerita yang memiliki gambaran tentang relasi Ibu dan anak, terdapat 15 cerita yang menggambarkan mengenai arketipe peran Ibu yang mengalami transformasi. Transformasi yang dimaksud adalah adanya perubahan pada karakter Ibu di dalam penceritaan karena adanya suatu pemicu tertentu. Kelima belas cerita tersebut sebagai berikut.

Tabel 3. Cerita Rakyat dengan Peran Ibu yang Bertransformasi

\begin{tabular}{|c|c|c|c|c|}
\hline No & Judul & Asal & Peristiwa dalam Cerita & $\begin{array}{c}\text { Deskripsi Peran } \\
\text { Ibu }\end{array}$ \\
\hline 1 & $\begin{array}{l}\text { Asal Mula } \\
\text { Kolam } \\
\text { Sampuraga }\end{array}$ & Sumatera Utara & $\begin{array}{l}\text { Ibu Sampuraga adalah seorang yang sangat } \\
\text { menyayangi Sampuraga. Hal ini terlihat dari } \\
\text { kegigihannya dalam bekerja di ladang untuk } \\
\text { memenuhi kehidupannya dan anak laki-lakinya. } \\
\text { Ibu Sampuraga sangat sabar menunggu kabar } \\
\text { dari Sampuraga yang telah bertahun-tahun } \\
\text { merantau ke negeri Mandailing. Bahkan ketika } \\
\text { Ibu Sampuraga mendapat kabar bahwa anaknya } \\
\text { akan menikah, Ibu Sampuraga langsung } \\
\text { menyusul Sampuraga ke Mandailing. Ibu }\end{array}$ & $\begin{array}{l}\text { Sayang dan sabar } \\
\text { menjadi murka dan } \\
\text { benci }\end{array}$ \\
\hline
\end{tabular}




\begin{tabular}{|c|c|c|c|c|}
\hline & & & $\begin{array}{l}\text { Sampuraga tega mengutuk Sampuraga karena } \\
\text { dihina anaknya di depan umum. Akhirnya } \\
\text { Sampuraga beserta calon istrinya meninggal } \\
\text { terendam banjir kutukan. }\end{array}$ & \\
\hline 2 & $\begin{array}{l}\text { Asal Mula } \\
\text { Pulau Si } \\
\text { Kantan }\end{array}$ & Sumatera Utara & $\begin{array}{l}\text { Ibu Si Kantan adalah seorang janda yang gigih } \\
\text { dalam bertani demi memenuhi kehidupannya } \\
\text { bersama anak laki-lakinya yaitu Kantan. Ibu Si } \\
\text { Kantan tega mengutuk Kantan karena perlakuan } \\
\text { Kantan yang sudah keterlaluan tidak mengakui } \\
\text { Ibunya sendiri. }\end{array}$ & $\begin{array}{l}\text { Sayang dan sabar } \\
\text { menjadi murka dan } \\
\text { benci }\end{array}$ \\
\hline 3 & $\begin{array}{c}\text { Legenda } \\
\text { Batang Tuaka }\end{array}$ & Riau & $\begin{array}{l}\text { Ibu adalah seorang janda anak satu. Ibu sangat } \\
\text { menyayangi anaknya bernama Tuaka. Bahkan } \\
\text { ia bekerja keras dengan mencari kayu ke hutan } \\
\text { demi menyambung kelangsungan hidupnya. } \\
\text { Namun, suatu ketika Ibu kehilangan } \\
\text { kesabarannya hingga ia mengutuk Tuaka } \\
\text { menjadi burung lantaran ia tidak diakui sebagai } \\
\text { Ibu oleh anaknya. }\end{array}$ & $\begin{array}{l}\text { Sayang dan sabar } \\
\text { menjadi murka dan } \\
\text { benci }\end{array}$ \\
\hline 4 & $\begin{array}{l}\text { Putri Tujuh } \\
\text { (Asal Mula } \\
\text { Nama Kota } \\
\text { Dumai) }\end{array}$ & Riau & $\begin{array}{l}\text { Ratu Cik Sima adalah seorang pemimpin } \\
\text { kerajaan sekaligus Ibu dari tujuh putrinya yang } \\
\text { elok rupawan. Sebenarnya ia memiliki sifat } \\
\text { yang sangat penyayang dan peduli pada } \\
\text { ketujuh anaknya. Hal ini terlihat ketika istana } \\
\text { diserang, Ratu Cik Sima mengamankan ketujuh } \\
\text { putrinya ke lubang bawah tanah di hutan yang } \\
\text { beratapkan tanah dan pohon serta membekali } \\
\text { anaknya makanan selama } 3 \text { bulan. Setelah itu, } \\
\text { Ratu kembali ke istana untuk berperang. } \\
\text { Namun, ia lupa bahwa perang berlangsung } \\
\text { selama } 4 \text { bulan sedangkan bekal untuk anak- } \\
\text { anaknya hanya cukup untuk } 3 \text { bulan. Oleh } \\
\text { karena kelalaiannya, ketujuh putrinya } \\
\text { meninggal kelaparan. }\end{array}$ & $\begin{array}{l}\text { Penyayang, sangat } \\
\text { peduli pada anak- } \\
\text { anaknya, namun } \\
\text { kurang hati-hati/lalai }\end{array}$ \\
\hline 5 & Si Lancang & Riau & $\begin{array}{l}\text { Ibu adalah seorang yang sudah sangat tua } \\
\text { namun tetap bekerja keras pergi ke ladang } \\
\text { untuk menghidupinya dan anak laki-lakinya } \\
\text { bernama si Lancang. Namun, ketika Si } \\
\text { Lancang sudah kaya raya justru tidak mengakui } \\
\text { Ibunya dan mencaci di depan banyak orang. } \\
\text { Karena hal tersebut, Ibu mengutuk Lancang } \\
\text { hingga kapal yang ditumpangi Lancang hancur } \\
\text { dan menewaskannya. }\end{array}$ & $\begin{array}{l}\text { Sayang dan sabar } \\
\text { menjadi murka dan } \\
\text { benci }\end{array}$ \\
\hline 6 & $\begin{array}{c}\text { Batu } \\
\text { Batungkup }\end{array}$ & Riau & $\begin{array}{l}\text { Mak Minah adalah seorang janda yang selalu } \\
\text { bekerja keras menghidupi ketiga anaknya yang } \\
\text { malas serta nakal bernama Utuh, Ucin, dan } \\
\text { Diang. Ketiga anaknya tidak pernah } \\
\text { membantunya sama sekali bekerja, awalnya ia } \\
\text { tetap sabar namun karena anak-anaknya sangat } \\
\text { nakal ia menyerahkan diri pada batu batungkup } \\
\text { untuk memakannya karena sudah muak dengan } \\
\text { tingkah laku ketiga anaknya. }\end{array}$ & $\begin{array}{l}\text { Penyayang, pekerja } \\
\text { keras, sabar, putus asa } \\
\text { karena tingkah laku } \\
\text { anak yang keterlaluan }\end{array}$ \\
\hline 7 & $\begin{array}{l}\text { Semesat dan } \\
\text { Semesit }\end{array}$ & Sumatera Selatan & $\begin{array}{l}\text { Seorang Ibu tiri yang awalnya sangat } \\
\text { menyayangi kedua anak sambungnya.namun } \\
\text { lama-kelamaan ia berhianat dan tega mengusir } \\
\text { kedua anak tirinya. Hal tersebut dilakukan } \\
\text { karena hanya ingin menguasai harta suaminya. }\end{array}$ & $\begin{array}{l}\text { Baik dan penyayang } \\
\text { menjadi bermuka dua } \\
\text { dan tamak }\end{array}$ \\
\hline 8 & $\begin{array}{l}\text { Asal Mula } \\
\text { Nama } \\
\text { Lempur, } \\
\text { Tebat Gelang, } \\
\text { dan Tebat } \\
\text { Jambi }\end{array}$ & Jambi & $\begin{array}{l}\text { Ibu adalah seorang Ibu dari Putri Pamuncak } \\
\text { Tanjung Sari yang sangat perhatian pada Putri. } \\
\text { Ia sangat sabar walaupun disebut sebagai } \\
\text { pembantu oleh anaknya sendiri. Namun lama } \\
\text { kelamaan kesabarannya telah habis, akhirnya } \\
\text { Ibu mengutuk Putri hingga tenggelam ditelan } \\
\text { lumpur. }\end{array}$ & $\begin{array}{l}\text { Perhatian dan sabar } \\
\text { menjadi kehilangan } \\
\text { kesabaran }\end{array}$ \\
\hline 9 & $\begin{array}{c}\text { Legenda Batu } \\
\text { Balai }\end{array}$ & Bangka Belitung & $\begin{array}{l}\text { Ibu adalah seorang janda beranak laki-laki } \\
\text { bernama Dempu Nawang. Ia sangat } \\
\text { menyayangi anaknya hingga mengizinkan }\end{array}$ & $\begin{array}{l}\text { Sayang dan sabar } \\
\text { menjadi murka dan } \\
\text { benci } \\
\end{array}$ \\
\hline
\end{tabular}




\begin{tabular}{|c|c|c|c|c|}
\hline & & & $\begin{array}{l}\text { anaknya merantau untuk mengubah garis } \\
\text { kemiskinan dalam hidup mereka. Setelah } \\
\text { sukses Dempu justru tidak mengakui Ibunya. } \\
\text { Akhirnya Dempu dikutuk berubah menjadi } \\
\text { batu. }\end{array}$ & \\
\hline 10 & $\begin{array}{l}\text { Legenda } \\
\text { Gunung } \\
\text { Pinang }\end{array}$ & Banten & $\begin{array}{l}\text { Sosok Ibu yang sangat menyayangi Dampu } \\
\text { Awang. Beliau awalnya menolak permintaan } \\
\text { Dampu untuk merantau, namun lama kelamaan } \\
\text { diizinkan. Setelah kaya di perantauan, Dampu } \\
\text { tidak mengakui Ibunya sendiri. Sang Ibu marah } \\
\text { dan mengutuk Dampu hingga kapal yang } \\
\text { ditumpanginya terlempar jauh dan } \\
\text { menewaskan Dampu. }\end{array}$ & $\begin{array}{l}\text { Sayang dan sabar } \\
\text { menjadi murka dan } \\
\text { benci }\end{array}$ \\
\hline 11 & $\begin{array}{c}\text { Batu } \\
\text { Menangis }\end{array}$ & Kalimantan Barat & $\begin{array}{l}\text { Ibu diceritakan sebagai sosok pekerja keras } \\
\text { karena setiap hari buruh di sawah dan ladang } \\
\text { orang untuk menyambung hidupnya dan } \\
\text { menuruti semua emauan sang anak. Ia sangat } \\
\text { menyayangi putrinya bernama Darmi walaupun } \\
\text { anaknya malas bekerja. Ibu Darmi yang terus } \\
\text { menerus disebut pembantu oleh anaknya, } \\
\text { murka dan mengutuk Darmi hingga berubah } \\
\text { menjadi batu. }\end{array}$ & $\begin{array}{l}\text { Sayang dan sabar } \\
\text { menjadi murka dan } \\
\text { benci }\end{array}$ \\
\hline 12 & $\begin{array}{c}\text { Legenda } \\
\text { Gunung Batu } \\
\text { Bangkai }\end{array}$ & Kalimantan Selatan & $\begin{array}{l}\text { Ibu Andung sangat menyayangi anaknya } \\
\text { dengan tulus. Namun saat Andung telah } \\
\text { merantau dan sukses ia justru tidak mengakui } \\
\text { Ibunya. Karena hal tersebut sang Ibu kecewa } \\
\text { dan mengutuk Andung hingga berubah menjadi } \\
\text { batu bangkai. }\end{array}$ & $\begin{array}{l}\text { Sayang dan sabar } \\
\text { menjadi murka dan } \\
\text { benci }\end{array}$ \\
\hline 13 & $\begin{array}{c}\text { Batu Bini dan } \\
\text { Batu Laki }\end{array}$ & Kalimantan Selatan & $\begin{array}{l}\text { Ibu Anuai awalnya sangat menyayangi } \\
\text { anaknya. Namun Ibu mengutuk Anuai menjadi } \\
\text { batu karena ia tidak mengakui Ibunya. }\end{array}$ & $\begin{array}{l}\text { Sayang dan sabar } \\
\text { menjadi murka dan } \\
\text { benci }\end{array}$ \\
\hline 14 & $\begin{array}{l}\text { Asal Mula } \\
\text { Burung } \\
\text { Ntaapo-Apo }\end{array}$ & Sulawesi Tenggara & $\begin{array}{l}\text { Ibu adalah sosok yang sangat menyayangi } \\
\text { putranya yaitu La Ane. Namun lama kelamaan } \\
\text { Ibu seringkali memarahi La Ane bahkan tidak } \\
\text { menyiapkan makanan untuk anaknya. Hal ini } \\
\text { karena anaknya sangat malas dan hanya } \\
\text { bermain gasing. La Ane yang mengetahui } \\
\text { Ibunya sudah tidak menyayanginya, lalu } \\
\text { berdoa pada Tuhan dan ia berubah menjadi } \\
\text { burung. }\end{array}$ & $\begin{array}{l}\text { Penyayang namun } \\
\text { lama-lama menjadi } \\
\text { pemarah karena } \\
\text { kelakuan anaknya } \\
\text { yang malas }\end{array}$ \\
\hline 15 & La Sirimbone & Sulawesi Tenggara & $\begin{array}{l}\text { Ibu Wa Roe adalah seorang janda cantik } \\
\text { beranak satu bernama La Srimbone. Semenjak } \\
\text { Ibu dinikahi laki-laki bernama La Patamba Ibu } \\
\text { berubah menjadi jahat dan tega membuang } \\
\text { anaknya sendiri demi menuruti suaminya. }\end{array}$ & $\begin{array}{l}\text { Sayang dan sabar } \\
\text { menjadi jahat }\end{array}$ \\
\hline
\end{tabular}

Tabel 3 berisikan mengenai cerita rakyat Nusantara yang memiliki gambaran mengenai arketipe peran Ibu yang mengalami transformasi. Pada ke-15 cerita tampak bahwa terdapat perubahan sikap yang ada pada diri tokoh Ibu yang disebabkan oleh adanya peristiwa tertentu. Perubahan ini, perlu dipahami sebagai bentuk ketidakstabilan pada peran Ibu dalam hubungannya antara Ibu-anak.

Arketipe peran Ibu yang bertransformasi dalam cerita rakyat Nusantara, yaitu 1) Transformasi dari sosok sabar dan sayang menjadi murka dan benci yang tampak pada cerita "Asal Mula Kolam
Sampuraga" dari Sumatera Utara, "Asal Mula Pulau Si Kantan" dari Sumatera Utara, "Legenda Batang Tuaka" dari Riau, "Si Lancang" dari Riau, "Legenda Batu Balai" dari Bangka Belitung, "Legenda Gunung Pinang" dari Banten, "Batu Menangis" dari Kalimantan Barat, "Legenda Gunung Batu Bangkai" dari Kalimantan Selatan, dan "Batu bini dan Batu Laki" dari Kalimantan Selatan, 2) Penyayang dan sangat peduli pada anak, tetapi menjadi sosok yang lalai tidak bertanggung jawab tampak pada cerita "'Putri tujuh" dari Riau, 3) Penyayang dan sabar menjadi sosok yang putus asa tampak pada cerita "Batu Batungkup" dari Riau, 4) 
Baik dan penyayang menjadi bermuka dua dan tamak tampak pada cerita "Semesat dan Semesit" dari Sumatera Selatan, 5) Penyayang namun lama-lama menjadi pemarah karena kelakuan anaknya yang malas tampak pada cerita "asal Mula Burung Ntaapo-Apo" dari Sulawesi Tenggara, dan 6) sayang dan sabar menjadi jahat tampak pada cerita "Li Sirimbone" dari Sulawesi Tenggara.

Dari gambaran tersebut tampak bahwa aspek transformasi peran Ibu terhadap anak yang tergambarkan dalam cerita adalah perubahan dari Ibu yang baik menjadi Ibu yang buruk. Gambaran mengenai transformasi yang berkebalikan tidak tampak dalam cerita. Arketipe peran ini memperlihatkan bahwa dalam pola pengasuhan orang tua (Ibu) terhadap anaknya akan memungkinkan terjadi transformasi peran pengasuhan jika anak melakukan perbuatan yang dilarang atau tidak disukai oleh Ibu ataupun munculnya tokoh lain yang ikut mempengaruhi keputusan yang diambil oleh Ibu. Gambaran mengenai hal ini masih tetap lestari dalam kultur masyarakat Nusantara hingga saat ini, seperti adanya stigma anak durhaka dan kutukan Ibu yang akan menimpa anak yang tidak menyayangi dan menghormati Ibunya (Juliastuty, 2018; Junus, 2001).

Posisi artiketipe ini dapat diinterpertasikan bahwa cerita-cerita ini menjadi lembaga bagi pelestarian norma mengenai Ibu dan sifat transformasi yang akan terjadi. Melalui simbolisasi peristiwa "peringatan" terhadap anak yang menentang ataupun menyalahi norma perilaku terhadap Ibu dapat terjadi. Keenambelas cerita ini menjadi alat pembelajaran dan sarana pelembagaan dan pewarisan norma hubungan antara Ibu dan anak yang hidup di masyarakat hingga saat ini.

\subsection{Arketipe peran Ibu bagi terapi lintas budaya \\ Dengan semakin meningkatnya praktisi dan peneliti dalam bidang terapi seni, mereka menyadari bahwa berbagai perkembangan yang selama ini ada bersifat}

Eurosentris (Hocoy, 2002). Para terapis juga perlu memahami bahwa pasien yang mereka tangani berasal dari berbagai latar belakang budaya, khususnya masyarakat non-Eropa atau non-Amerika. Untuk menangani pasien ini diperlukan pendekatan budaya yang berbeda. Ketidakpahaman akan latar belakang budaya pasien akan menyebabkan kesalahpahaman dan kesalahan treatment kepada pasien (Hocoy, 2002). Karenanya, dIbutuhkan hasil-hasil riset yang berasal dari berbagai negara mengingat heterogonitas masyarakat yang ada di dunia ini.

Menyikapi hal tersebut, telah sejak lama para peneliti mulai mengumpulkan berbagai produk budaya masyarakat untuk mengenali karakteristik (pola pikir dan perilaku) suatu masyarakat kelompok budaya. Para ahli menyadari cerita rakyat (dongeng, mitos, legenda, saga, dan lain-lain) telah lama digunakan oleh para peneliti budaya untuk memahami karakteristik suatu kelompok budaya. Riset-riset terhadap karya sastra tersebut para ahli psikoterapi dapat memanfaatkannya dalam kegiatan praktik terapi lintas budaya.

Brown (2008) melakukan penelitian terhadap dongeng. Ia menemukan bahwa dongeng sepatutnya tidak hanya dikonsumsi anak-anak karena menyimpan pesan kultural penting di dalamnya. Berdasarkan studinya ia menyimpulkan orang yang mengalami gangguan rasa takut, pengabaian, persaingan saudara, direndahkan harga dirinya, hingga mengalami kehampaan dalam hidup dapat memanfaatkan dongeng sebagai titik awal diskusi dalam terapi. Dalam konteks lain, misalnya, Fleer \& Hammer (2013), menyatakan dongeng memiliki tempat yang penting dalam anak usia dini karena memperkenalkan situasi imajinatif yang bermuatan emosional dan mendukung relugasi emosi anak-anak dalam situasi pengasuhan tertentu. Bahkan, dalam perspektif pedagogis, dongeng menjadi alat yang ampuh untuk menumbuhkan perspesi dan reaksi emosi pada anak (Hohr, 2000). Karenanya diperlukan riset-riset budaya yang mampu membedah "nilai" budaya yang hidup dan mengendap dalam berbagai 
produk budaya masyarakat, seperti karya sastra. Melalui studi yang telah dilakukan, Walker (2010), menyatakan mitos, legenda, dan dongeng menawarkan sumber materi yang kaya untuk dimanfaatkan dalam bidang terapeutik. Berbagai hasil studi tersebut memperlihatkan nilai guna cerita dalam membantu seseorang ataupun kelompok dalam menciptakan makna dari pengalaman hidupnya (Sommer et al., 2012).

Selain itu, para peneliti juga menemukan efektivitas penggunaan media terapi sastra terhadap penurunan tingkat stres pekerja (Huet, 2015), mengatasi trauma dan penyakit mental (Avrahami, 2005; Regev \& Cohen-Yatziv, 2018; Smith, 2016; Van Lith, 2016), meningkatkan kondisi psikologis dan menurunkan tingkat kecemasan (Ruini et al., 2014). Berbagai hal tersebut membuktikan bahwa karya sastra memiliki fungsi yang penting dalam bidang terapi. Terlebih dengan tumbuhnya kesadaran akan multikulturalisme dalam berbagai bidang, pemahaman terhadap keunikan karakteristik budaya setiap pasien mendapatkan posisi yang penting. Hal ini karena keberhasilan terapi dipengaruhi oleh pemahaman latar belakang budaya pasien oleh terapis (Tsang et al., 2011). Bahkan Lee \& Horvath menyarakan sangat diperlukan pelatihan kepada terapis, utamanya terhadap pemahaman lintas budaya dalam praktik terapi (Lee \& Horvath, 2014).

Berbagai hal tersebut memperlihatkan bahwa dalam bidang terapi, kesadaran keanekaragaman latar belakang budaya pasien sangatlah penting. Pemahaman ini berimplikasi terhadap cara penanganan dan pemahaman terhadap pasien yang dihadapi.

Pada bagian sebelumnya telah dijabarkan interpertasi terhadap arketipe peran Ibu dalam cerita rakyat Nusantara. Berdasarkan analisis yang dilakukan ditemukan 64 cerita yang memiliki gambaran mengenai hubungan antara Ibu dan anak. Berbagai gambaran tersebut merwujud dalam bentuk simbolisasi peran Ibu dan anak. Gambaran arketipe mental budaya peran Ibu dan anak sebagai imajinasi kolektif masyarakat nusantara dapat digambarkan dalam gambar 1 .

Gambar 1 merupakan tambaran arketipe mental budaya peran Ibu yang ditemukan dalam 64 cerita rakyat nusantara yang dianalisis. Secara mendasar, peran Ibu dalam hubungannya dalam hubungan Ibu-anak, mencerminkan 3 bentuk arketipe peran mendasar, yaitu adanya mentalitas imajinasi Ibu yang baik, Ibu yang jahat, dan sosok Ibu yang mengalami transformasi peran. Masing-masing imajinasi mengenai peran Ibu terepresentasikan melalui beragam tindakan, seperti Ibu yang baik 1) berkorban demi anak, 2) bekerja keras demi anak, 3) pengasuh, 4) pelindung, dan 5) guru bagi anaknya. Ibu yang buruk 1) menelantarkan anak, 2) egois, 3) kejam, 4) serakah, dan 5) tega membunuh anaknya. Di sisi lain tranformasi peran Ibu yaitu 1) sabar dan saying menjadi murka dan benci pada anaknya, 2) saying dan peduli menjadi alali tidak bertanggung jawab, 3) saying dan sabar menjadi putus asa, 4) baik dan penyayang menjadi bermuka dua dan tamak, 5) sayang menjadi pemarah, dan 6) sayang dan sabar menjadi jahat.

Analisis tekstual terhadap berbagai arketipe mental budaya peran Ibu dalam cerita rakyat Nusantara mengungkapkan peran sentral Ibu dalam aspek kehidupan manusia Nusantara. Ibu menjadi sosok penting dalam imajinasi kultural karena menjadi sosok protagonis dan antagonis yang mampu mengubah peranannya sesuai dengan konteks situasi yang menyertainya. Ibu bisa menjadi sosok pelindung sekaligus menjadi sosok yang tega membunuh anak kandungnya sendiri. Gambaran ini membantu menjelaskan pengajaran kedisiplinan menahan diri dan emosi dalam pengasuhan orang tua. Konsep seperti keutamaan Ibu dibandingkan ayah dalam kutlur masyarakat juga dapat dijelaskan berdasarkan aspek dominasi peran dan intensitas kemunculan tokoh-tokoh Ibu yang bergerak di ranah domestik, yang berkaitan dengan pengasuhan anak. Hampir tidak ditemukan peran sentral Ayah dalam pengasuhan anak dalam cerita rakyat selain 
pengambilan keputusan yang berkaitan dengan ranah publik anak.

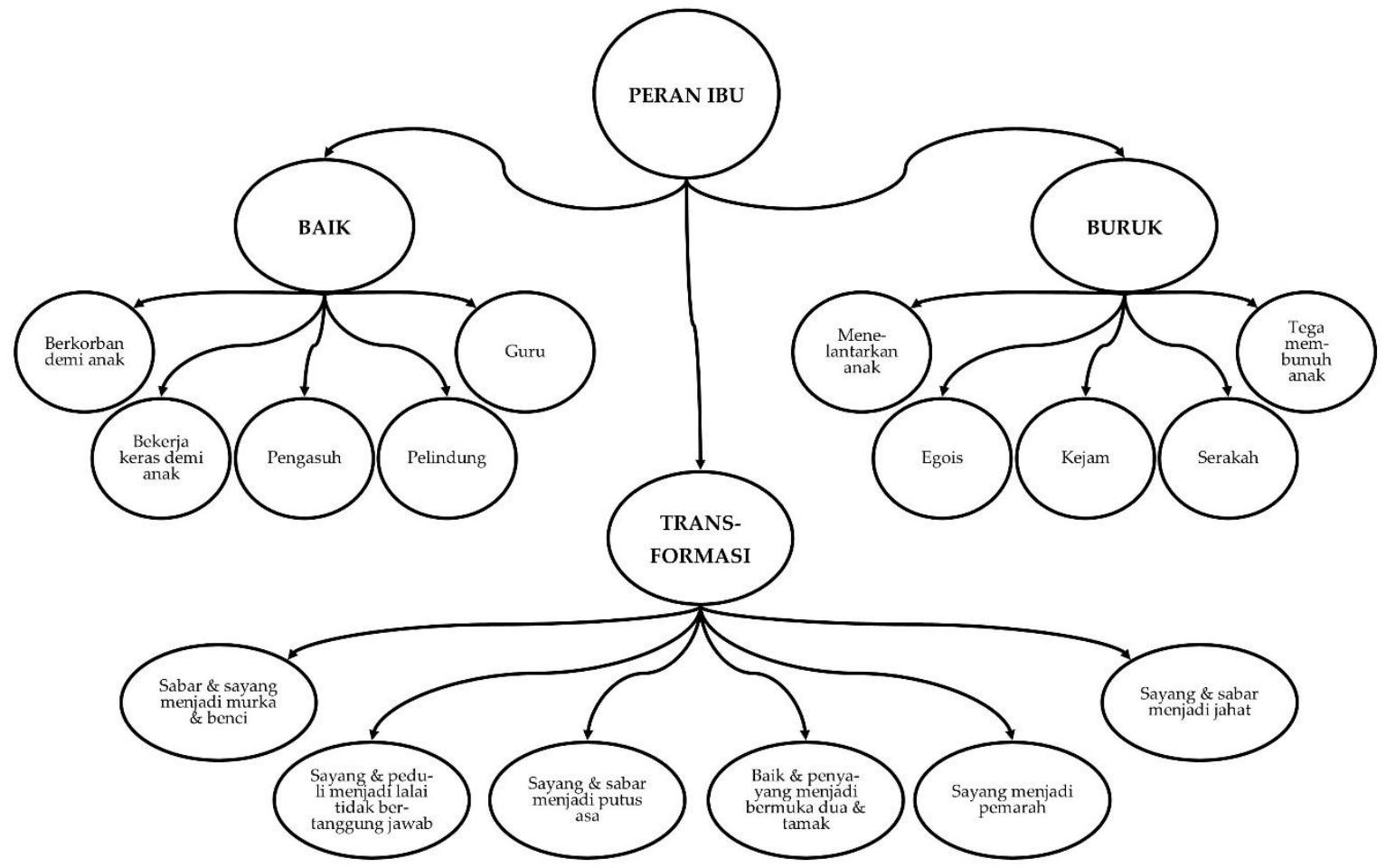

Gambar 1 Arketipe mental budaya peran Ibu dalam Cerita Rakyat Nusantara (Sumber: dokumentasi pribadi penulis)

Keragaman gambaran peran Ibu dalam cerita rakyat nusantara dapat dimanfaatkan utamaya berkaitan dengan proses terapi dalam menjalin hubungan dengan pasiennya. Cerita dongeng, khususnya, dapat digunakan untuk meningkatkan keterlibatan pasien anak-anak ketika dialog secara konvensional tidak memadai atau tidak berhasil dalam proses terapeutik. Kedekatan berbagai mental peran Ibu dalam cerita rakyat yang terus dilembagakan dan diwariskan antargenerasi dapat menjadi contoh dalam membangun konstruksi perkembangan kepribadian anak (Walker, 2010). Hal ini dapat menawarkan kesempatan kepada anak untuk memahami berbagai makna dan pengaruh yang terkandung di dalam cerita. Utamanya bagaimana relasi antara kondisi psikologis pasien, khususnya anak-anak, dengan terapisnya.
Dalam kehidupan sehari-hari, peran Ibu sebagai sosok sentral dalam kehidupan kolektif masyarakat Nusantara juga sering digunakan dalam kegiatan yang menyasar aspek psikologis. Misalnya, pada kegiatan tertentu biasanya sosok Ibu digunakan sebagai penyemangat sekaligus sebagai sosok yang digunakan untuk menakuti atau mencegah suatu perbuatan. Betapa takutnya seseorang atau betapa tersentuhnya seseorang ketika berbagai hal yang dilakukan diasosiasikan dengan keberadaan Ibunya.

Penggunaan cerita dalam proses terapi telah lama dipercaya sebagai strategi komunikasi terapi, khususnya pada pasien anak-anak, yang efektif (Perret-Catipovic \& Ladame, 1998). Melalui pemilihan cerita yang relevan dengan kondisi dan dekat secara kultural dapat memberikan kesempatan kepada pasien untuk memahami 
pesan pada tingkatan moral di dalamnya. Melalui hal ini terapis dapat memanfaatkan narasi berdasarkan karakteristik peran Ibu yang ada di dalamnya sebagai saran untuk memperoleh wawasan tentang dunia dalam dan dunia luar anak yang menjadi pasien terapisnya.

\section{Kesimpulan}

Penelitian

ini bertujuan

mendeksripsikan arketipe peran Ibu dalam cerita rakyat nusantara sebagai gambaran mental budaya masyarakat dan signifikansi arketipe peran Ibu sebagai mental budaya masyarakat Indonesia dapat berkontribusi terhadap terapi lintas budaya. Berdasarkan analisis yang dilakukan ditemukan bahwa dalam imajinasi kolektif masyarakat Nusantara, Ibu memiliki peran yang sangat penting. Ibu tidak hanya menjadi sosok protagonis yang memberikan perlindungan, kehidupan, dan kesejahteraan, tetapi juga menjadi antagonis yang mampu menjadi sosok menakutkan bagi anaknya. Dalam oposisi biner, sosok Ibu juga mampu bertranformasi perannya dengan mengubah peranannya sesuai dengan konteks situasi yang menyertainya. Kecenderungan ini dari Ibu protagonis menjadi sosok antagonis yang diakibatkan oleh situasi yang disebabkan ketidakpatuhan anaknya atau hadirnya pihak ketiga.

Dalam cerita rakyat nusantara arketipe mental budaya peran Ibu mencakup tiga gambaran, yaitu Ibu yang baik adalah yang 1) berkorban demi anak, 2) bekerja keras demi anak, 3) pengasuh, 4) pelindung, dan 5) guru bagi anaknya. Ibu yang buruk adalah yang 1) menelantarkan anak, 2) egois, 3) kejam, 4) serakah, dan 5) tega membunuh anaknya. Di sisi lain tranformasi peran Ibu yaitu 1) sabar dan sayang menjadi murka dan benci pada anaknya, 2) saying dan peduli menjadi alali tidak bertanggung jawab, 3) saying dan sabar menjadi putus asa, 4) baik dan penyayang menjadi bermuka dua dan tamak, 5) sayang menjadi pemarah, dan 6) sayang dan sabar menjadi jahat.

Ketiga arketipe tersebut merupakan gambaran dari imajinasi kolektif masyarakat
Nusantara dalam menggambarkan peran Ibu dalam kehidupan sehari-hari. Gambaran ini dapat dimanfaatkan dalam bidang terapi, khususnya dalam proses terapi yang melibatkan pasien anak-anak atau Ibu. Arketipe peran Ibu dapat menjadi gambaran mengenai nilai-nilai yang melekat pada sosok Ibu dan menjadi mental budaya masyarakat Nusantara selama ini.

Penelitian ini cukup banyak memiliki kekurangan. Penelitian ini dilakukan dengan menitikberatkan pada aspek interpretasi tekstual terhadap cerita rakyat Nusantara untuk menemukan arketipe peran Ibu dalam cerita sebagai gambaran mental budaya masyarakat Nusantara. Aspek relevansinya dengan terapi lintas budaya tidak didasarkan pada studi mendalam, tetapi hanya didasarkan pada studi dokumen terbatas. Hal ini karena bidang tersebut di luar bidang keilmuan penulis. Untuk itu, peneliti selanjutnya dapat melakukan penelitian lanjutan terhadap hal tersebut.

\section{Daftar Pustaka}

Abrams, P. (2021). The Bad mother: Stigma, abortion and surrogacy. Journal of Law, Medicine \& Ethics, 43(2), 179-191. https://doi.org/10.1111/jlme.12231

Andalas, E. F. (2015). Mitos-Mitos Kabupaten Malang: Cara orang Jawa dalam menjelaskan dunianya. Puitika, 11(2), 150-162. https://www.researchgate.net/publicatio n/323113958_Mitos-

Mitos_Kabupaten_Malang_Cara_Oran g_Jawa_dalam_Menjelaskan_Dunianya

Andalas, E. F. (2018). Cerita rakyat dan tradisi masyarakat agraris Nusantara: Mitos Dewi Sri (Jawa) dan Legenda Putri Mandalika (Sasak). In Puji Karyanto (Ed.), Kisah-Kisah Perempuan dan Cerita Rakyat Nusantara2 (pp. 1-12). Kajian Sastra dan Budaya Universitas Airlangga.

Aristama, M. F., Andalas, E. F., \& Sugiarti, S. (2020). Dampak dan fungsi mite Semar bagi kehidupan masyarakat 
lereng Gunung Arjuna. Poetika, 8(1), 112. https://doi.org/10.22146 /poetika.55300

Avrahami, D. (2005). Visual art therapy's unique contribution in the treatment of Post-Traumatic Stress Disorder. Journal of Trauma and Dissociation, $6(4), 5-38$.

Bar Zaken, S. (2020). Folktales in assistance of cross-culture therapy: cultural mental prototype of motherhood in Russian folktales. Journal of Poetry Therapy, 33(4), 236-251. https://doi.org/10.1080/08893675.2020. 1803615

Brown, N. W. (2008). Therapeutic use of space: One agency's transformation project. Journal of Creativity in Mental Health, 2(4), 31-44. https://doi.org/10.1300/J456v02n04

Congxin, S., \& Yongxia, Q. (2019). A Jungian analysis of the archetypal image of the fish from a Chinese cultural perspective. Journal of Humanistic Psychology, 1-20. https://doi.org/10.1177/0022167819850 947

Diala-Ogamba, B. (2015). Folktales as African childrens literature: A study of archetypal symbols in selected Igbo folktales. In E. N. Emenyonu (Ed.), Childrens Literature and Story-telling (pp. 54-68). Boydell \& Brewer, James Currey.

Dundes, A. (1969). Folklore as a Mmirror of culture. Elementary English, 46(4), 471-482.

http://www.jstor.org/stable/41386525

Fleer, M., \& Hammer, M. (2013). Emotions in imaginative situations: The valued place of fairytales for supporting emotion regulation. Mind, Culture, and Activity, 20(3), 240-259. https://doi.org/10.1080/10749039.2013. 781652
Greene, M. (2011). Using myths, legends and fairy tales in counselling: Archetypal motifs underlying the mother complex. Asia Pacific Journal of Counselling and Psychotherapy, 2(1), 41-50. https://doi.org/10.1080/21507686.2010. 546418

Hocoy, D. (2002). Cross-cultural issues in art therapy. Art Therapy, 19(4), 141145.

https://doi.org/10.1080/07421656.2002. 10129683

Hohr, H. (2000). Dynamic aspects of fairy tales: Social and emotional competence through fairy tales. Scandinavian Journal of Educational Research, 44(1), 89-103.

https://doi.org/10.1080/713696665

Huet, V. (2015). Literature review of art therapy-based interventions for workrelated stress. International Journal of Art Therapy: Inscape, 20(2), 66-76. https://doi.org/10.1080/17454832.2015. 1023323

Johns, A. (2004). Baba Yaga: The ambiguous mother and witch of the Russian folktale. Peter Lang.

Juliastuty, D. (2018). Kutukan Menjadi Batu Pada Lima Legenda di Indonesia. Tuah Talino, 12(1), 123-140. https://doi.org/10.26499/tt.v12i1.1105

Jung, C. G. (2014). The archetypes and the collective unconscious. Routledge.

Junus, U. (2001). Malin Kundang dan dunia kini. Sari: Jurnal Alam Dan Tamadun Melayu, 69, 69-83. http://journalarticle.ukm.my/1213/1/Ma lin_Kundang_dan_Dunia_Kini.pdf

Kaniel, R. K. I. (2015). The myth of the messianic Mother in Jewish and Christian traditions: Psychoanalytic and gender perspectives. Journal of the American Academy of Religion, 83(1), 73-119. 
https://doi.org/10.1093/jaarel/lfu078

Kheong, C. Q. W., Satkunananthan, A. H., \& Hamdan, S. I. (2019). Sang kancil as cultural artefact: A comparative neoarchetypal study. GEMA Online Journal of Language Studies, 19(4), 243-257. https://doi.org/10.17576/gema-20191904-13

Lee, E., \& Horvath, A. O. (2014). How a therapist responds to cultural versus noncultural dialogue in cross-cultural clinical practice. Journal of Social Work Practice, 28(2), 193-217. https://doi.org/10.1080/02650533.2013. 821104

Lestari, D., Helviani, H., \& Isnaini, H. (2018). Representasi nilai-nilai karakter pada tokoh Ibu dalam cerita rakyat "Timun Mas." Parole (Jurnal Pendidikan Bahasa dan Sastra Indonesia), 1(6), 911-918. https://doi.org/10.22460/p.v1i6p911918.1602

Masuku, N. (2020). Motherhood venerated in Zulu proverbs and folktales: The Africana- womanist approach. South African Journal of African Languages, 40(2), 218-222. https://doi.org/10.1080/02572117.2020. 1804287

Miles, B. M., \& Huberman, M. (1992). Analisis data kualitatif: Buku sumber tentang metode-metode baru. UIP.

Neumann, E. (2015). The Great Mother: An analysis of the archetype. Princeton University Press.

Perret-Catipovic, M., \& Ladame, F. (1998). Adolescence and psychoanalysis: The story and the history. Karnac Books.

Putra, A., \& Alias, A. (2018). Citra perempuan dalam cerita rakyat Waindho-Indhodhiyu pada masyarakat Wakatobi. ETNOREFLIKA: Jurnal Sosial Dan Budaya, 7(1), 20-29. https://doi.org/10.33772/etnoreflika.v7i

\subsection{8}

Regev, D., \& Cohen-Yatziv, L. (2018). Effectiveness of art therapy with adult clients in 2018-What progress has been made? Frontiers in Psychology, 9(AUG). https://doi.org/10.3389/fpsyg.2018.015 31

Ruini, C., Masoni, L., Ottolini, F., \& Ferrari, S. (2014). Positive narrative group psychotherapy: The use of traditional fairy tales to enhance psychological well-being and growth. Psychology of Well-Being, 4(1), 1-9. https://doi.org/10.1186/s13612-0130013-0

Sayers, J. (2014). Freud's artpsychoanalysis retold. Routledge.

Smith, A. (2016). A literature review of the therapeutic mechanisms of art therapy for veterans with post-traumatic stress disorder. International Journal of Art Therapy: Inscape, 21(2), 66-74. https://doi.org/10.1080/17454832.2016. 1170055

Soenarto, I., \& Tjahjani, J. (2019). Representations of Mother in Indonesian and European literary folktales. Proceedings of the 1st International Conference on Folklore, Language, Education and Exhibition (ICOFLEX 2019), 71-77. https://www.atlantispress.com/article/125950169.pdf

Sommer, C. A., Kholomeydek, N., Meacham, P., Thomas, Z., Bryant, M. L., \& Derrick, E. C. (2012). The supervisee with a thousand faces: Using stories to enhance supervision. Journal of Poetry Therapy, 25(3), 151-163. https://doi.org/10.1080/08893675.2012. 709716

Sue, D. W., \& Sue, D. (1999). Counseling the culturally different: Theory and practice. John Willey. 
Sue, D. W., \& Sue, D. (2003). Counseling the culturally diverse: Theory and practice (4 th). John Willey.

Sulistyorini, D., \& Andalas, E. F. (2017). Sastra lisan: Kajian teori dan penerapannya dalam penelitian. Madani.

Talwar, S., Iyer, J., \& Doby-Copeland, C. (2004). The invisible veil: Changing paradigms in the art therapy profession. Art Therapy, 21(1), 44-48. https://doi.org/10.1080/07421656.2004. 10129325

Tsang, A. K. T., Bogo, M., \& Lee, E. (2011). Engagement in cross-cultural clinical practice: Narrative analysis of first sessions. Clinical Social Work Journal, $39(1)$, 79-90. https://doi.org/10.1007/s10615-0100265-6
Van Lith, T. (2016). Art therapy in mental health: A systematic review of approaches and practices. Arts in Psychotherapy, 47, 9-22. https://doi.org/10.1016/j.aip.2015.09.00 3

Von Franz, M. L. (2017). The interpretation of fairy tales. Shambhala Publications.

Walker, S. (2010). Young people's mental health: The spiritual power of fairy stories, myths and legends. Mental Health, Religion and Culture, 13(1), 81-92.

https://doi.org/10.1080/1367467090319 6721 